


\section{The role of agrotourism in tourist season extension in Littoral Croatia}

\section{Agroturizam u funkciji produljenja turističke sezone Primorske Hrvatske}

The issue of seasonality in tourism is a growing concern for Littoral Croatia and has led to this complex research. Agrotourism is defined as tourism on rural tourist family farms. Based on research results, the general model of agrotourism development in Littoral Croatia has been created, because agrotourism in Croatia still is not systematically used as a tool for revitalization, the impact of seasonality reduction and year-round tourism product creation. The methodological approach in this research is based on telephone surveys, field survey and interviews with owners of rural tourist family farms. The survey covered a total of 58 holders in the 39 cities / municipalities. The sample is very relevant because it makes up $84.1 \%$ of the total of 69 owners who provided accommodation service in Littoral Croatia in 2012. The results show that agrotourism in Littoral Croatia confronts numerous problems and is in the initial stage of development. As such, agrotourism has a small role in reducing the impact of seasonality, but is also a significant potential for development. Greater engagement of the owners of family farms engaged in this type of tourism, as well as greater involvement on the part of the authorities, is sure to lead to agrotourism becoming one of the core elements of the development that will generate the necessary changes in the rural area, as it already has in the rural areas of some European countries.

Key words: agrotourism, seasonality, rural area, Littoral Croatia, rural tourist family farm
Rad predstavlja prvu kompleksnu analizu agroturizma u funkciji ublažavanja efekta sezonalnosti u Primorskoj Hrvatskoj. Agroturizam se pritom definira kao turizam koji se ostvaruje na turističkome seljačkom obiteljskom gospodarstvu (TSOG). Na osnovi rezultata istraživanja kreiran je opći model razvoja agroturizma u navedenom prostoru, čijom bi provedbom agroturizam pridonio revitalizaciji ruralnog prostora i stvaranju cjelogodišnjega turističkog proizvoda. Metodologija rada temelji se na metodi telefonskog i terenskog anketnog istraživanja te slobodnoga istraživačkog razgovora. Anketom je obuhvaćeno 58 TSOG-ova u 39 gradova/općina. Uzorak je izrazito relevantan jer čini 84,1 \% od ukupno 69 nositelja TSOG-ova koji pružaju uslugu smještaja u Primorskoj Hrvatskoj 2012. godine. Rezultati istraživanja pokazuju da je agroturizam u Primorskoj Hrvatskoj u početnoj fazi razvoja te vrlo malo pridonosi produljenju turističke sezone, ali ima ogroman neiskorišteni potencijal. Većim angažmanom nositelja tog oblika turizma te državnih ili upravnih tijela agroturizam može postati jedan od temeljnih elemenata razvoja koji će generirati nužne promjene u ruralnom prostoru, što je u dijelu europskih zemalja već ostvareno.

Ključne riječi: agroturizam, sezonalnost, ruralni prostor, Primorska Hrvatska, turističko seljačko obiteljsko gospodarstvo 


\section{Introduction}

By looking into the flows and activities of Croatian tourism, the well-known fact that Croatia is focused nowadays on the "sun and sea" tourist product can be identified. Comparison of tourist nights in rural Croatia with tourist nights of the entire country demonstrates that tourist nights in rural regions of Croatia participate with $2.9 \%$. This percentage relates to the 15 counties officially listed as counties of rural Croatia and it would be higher if omitted counties were included. However, even a corrected proportion of tourist nights in rural tourism in Croatia would be significantly lower as compared to the equivalent proportion on a European scale, which varies from 10 to 20\% (Baćac, 2011; Demonja and Ružić, 2010).

Due to the saturation of the tourism hot-spots in Croatia with supply focused almost exclusively on maritime tourism, different selective types of tourism start thriving which, besides expanded and higher quality tourist supply, enable extension of the tourist season (Blažević, 2003). One of them is rural tourism, which is a common term for all the segment types of tourism in rural areas (Demonja and Ružić, 2010). Behaviour of state and administrative institutions that Croatia should channel its investments almost exclusively towards the "sun and sea" tourist product has been contributing to marginalisation of rural tourism over the past decades. This is difficult to understand, as rural areas make up about $87 \%$ of the total surface area of Croatia (Demonja and Ružić, 2010) and contains huge unused potential, especially in the hinterland of the most developed Croatian tourist region - Littoral Croatia.

Since Croatia is characterised by the long-term process of parcel fragmentation and rural depopulation, the population whose source of income is agriculture faces existential problems. Under such circumstances, tourism is the only logical additional source of income that retains the population in the rural areas and contributes towards the revitalisation of the rural space in general. The most developed form of rural tourism most closely related to the two aforementioned economic sectors - agriculture and tourism - shapes the specific tourist supply that takes place on rural tourist family farms

\section{Uvod}

Sagledavanjem turističkog prometa i turističkih aktivnosti u okviru hrvatskog turizma, uočava se poznata činjenica da je Hrvatska danas pretežito okrenuta turističkom proizvodu „sunca i mora”. Usporedba ostvarenih noćenja ruralne Hrvatske s ukupno ostvarenim noćenjima pokazuje da noćenja u ruralnoj Hrvatskoj sudjeluju s 2,9 \%. Taj udio odnosi se na petnaest županija koje se službeno navode kao županije ruralne Hrvatske te bi on zasigurno bio veći kada bi se uključile izostavljene županije. Ostaje međutim činjenica kako bi i korigirani postotak noćenja koji se ostvaruje u ruralnom turizmu u Hrvatskoj bio znatno manji od ekvivalentnog udjela koji se ostvaruje u europskim okvirima, a iznosi od deset do dvadeset posto (Baćac, 2011; Demonja i Ružić, 2010).

Zbog zasićenja glavnih turističkih žarišta $\mathrm{RH}$ ponudom usmjerenom gotovo isključivo na kupališni turizam, počinju se razvijati razni oblici selektivnih vrsta turizma koji osim proširene i kvalitetnije turističke ponude omogućuju i produženje turističke sezone (Blažević, 2003). Među njima je i ruralni turizam, koji je zajednički naziv za sve segmentne oblike turizma u ruralnim područjima (Demonja i Ružić, 2010). Stav državnih ili upravnih tijela kako je nužno da Hrvatska svu svoju investicijsku klimu usmjeri prema turističkom proizvodu „sunca i mora” već desetljećima marginalizira turizam u ruralnom prostoru, što je teško shvatljivo s obzirom na činjenicu da ruralni prostor zauzima čak oko 87 \% površine Hrvatske (Demonja i Ružić, 2010) i sadržava golemi neiskorišteni prostorni potencijal, pogotovo u zaleđu najrazvijenije turističke regije Hrvatske - Primorske Hrvatske.

Kako je u Hrvatskoj prisutan dugotrajan proces usitnjavanja poljoprivrednih posjeda i depopulacije agrarnih prostora, stanovništvo čiji je izvor prihoda i dalje poljoprivreda suočava se s problemom opstanka. U takvim okolnostima turizam se nameće kao logičan dodatni izvor prihoda koji zadržava stanovništvo $\mathrm{u}$ ruralnom prostoru i pridonosi revitalizaciji rurisa. Najrazvijeniji oblik ruralnog turizma, koji ponajviše zadire u spomenuta dva gospodarska sektora poljoprivredu i turizam, oblikujući specifičnu turističku ponudu koja se odvija na seljačkome obiteljskom gospodarstvu, naziva se agroturizam, seljački turizam ili, najpreciznije, turizam na seljačkim obiteljskim gospo- 
(RTFF) ${ }^{1}$ (Brščić et. al., 2010; Towards Quality Rural Tourism, 2000). In this paper, the term agrotourism $^{2}$ will be used as it is most commonly used in practice, despite the fact that unique definition of this term does not exist in Croatian law.

Agrotourism encompasses vacation on a rural tourist family farm including services such as accommodation, food, beverages, entertainment, recreation and other, in family houses and other accommodation units (camps, boarding houses, hotels) within the limits of the family farm (Demonja and Ružić, 2010; Roberts and Hall, 2001).

Due to its specific features, such type of rural tourism can contribute to the development of rural areas by diversifying the local economy and reaching goals defined by the Main Plan and Strategy of Tourism Development in Republic of Croatia by 2020 (originally: Glavni plan i Strategija razvoja turizma Republike Hrvatske do 2020. godine), which includes "more than just sunshine and sea" and "tourism on the entire territory". The final product should include tourist season extension, which would significantly boost the Croatian economy.

Up until the 1990s, agrotourism was not a planned activity, while during the socialist era it was neglected due to the negative attitude towards private ownership, family farms and non-industrial production in general (Lukić, 2000). Preorientation of Croatia towards the free market and capitalism, reviving the private ownership and RTFFs, meaning that there is no reason nowadays for Croatia not to take all the steps necessary for intensifying integral ${ }^{3}$ development of rural areas. Their multisectoral economic development including rural (and thus agrar) tourism, makes up one of the key factors significantly influencing socioeconomic and physiognomic transformation of rural space (Defilippis, 1993; Pejnović, 2006; Lukić, 2000). darstvima (TSOG) ${ }^{1}$ (Brščić i dr., 2010; Towards Quality Rural Tourism, 2000). U ovome radu upotrebljavat će se termin agroturizam ${ }^{2}$ jer je u praksi najčešći unatoč još uvijek višeznačnoj definiranosti u hrvatskim zakonima.

Riječ je dakle o odmoru na seljačkom gospodarstvu (registriranome obiteljskom poljoprivrednom gospodarstvu, poljoprivrednome obrtu, poljoprivrednome trgovačkom društvu d.o.o. ili d.d.) s korištenjem uslugama smještaja, prehrane, pića, zabave, rekreacije i drugim uslugama, u obiteljskim kućama ili drugim objektima smještaja (kamp, pansion, hotel) u okviru seljačkoga obiteljskoga gospodarstva (Demonja i Ružić, 2010; Roberts i Hall, 2001).

Zbog svojih specifičnosti takav oblik ruralnog turizma može pridonijeti razvoju ruralnih područja diverzifikacijom lokalne ekonomije te ostvarenju ciljeva definiranih Glavnim planom i Strategijom razvoja turizma Republike Hrvatske do 2020. godine koji glase: "više od sunca i mora” te "turizam na cijelom prostoru". Konačni produkt trebao bi biti produljenje turističke sezone, koje bi značajno ojačalo cjelokupno hrvatsko gospodarstvo.

Sve do devedesetih godina 20. stoljeća agroturizam nije bio planiran, a u socijalističkom sustavu bio je i zapostavljen zbog negativnog stava prema privatnom vlasništvu, obiteljskim gospodarstvima te neindustrijskoj proizvodnji općenito (Lukić, 2000). Preorijentacijom Hrvatske na tržišno gospodarstvo i kapitalizam, oživljavanjem privatnog vlasništva i obiteljskih seljačkih gospodarstava, danas nema razloga da Hrvatska ne uloži potrebne napore u integralni razvoj ${ }^{3}$ ruralnih područja, pri čemu je multisektorski gospodarski razvoj s uključivanjem ruralnoga (a time i agrarnoga) turizma jedan od ključnih elemenata koji izrazito utječe na socioekonomsku i fizionomsku transformaciju ruralnog prostora (Defilippis, 1993; Pejnović, 2006; Lukić, 2000).

1 Rural tourist family farm (RTFF) is defined as a smaller economic unit located in a touristically attractive area, which offers an authentic product and service while, at the same time, all the family members are included in its operation. (Brščić et. al., 2010).

1 Turističko seljačko obiteljsko gospodarstvo (TSOG) definira se kao manja gospodarska cjelina smještena u turistički atraktivnom kraju koja daje izvoran proizvod ili uslugu gospodarstva, a u rad su uključeni svi članovi obitelji (Brščić i dr., 2010)

2 Except in the context of type of tourism, the term agrotourism is frequently used as a synonym for the rural tourist family farm. Where that happens, it occurs in the plural.

2 Osim u kontekstu vrste turizma termin agroturizam često se rabi i kao sinonim za turističko seljačko obiteljsko gospodarstvo, pa se u tom značenju javlja i u množini.

3 Integral development incorporates optimisation of all the physical and human resources, and it can be viewed in the context of sustainable development (Lukić, 2000).

3 Integralni razvoj podrazumijeva optimizaciju svih prirodnih, stvorenih i ljudskih resursa, a može se svesti pod pojam održivog razvoja (Lukić, 2000).

The role of agrotourism in tourist season extension in Littoral Croatia

Agroturizam u funkciji produljenja turističke sezone Primorske Hrvatske 
GEOGRAFSKI

GLASNIK

77/2,141-168 (2015.)
Examples of a number of European countries, for example, Austria and Scotland, confirm the aforementioned statements that agrotourism can contribute to rural areas revitalisation, but also alleviate the seasonal character of tourism. From the 1980s, Scotland has been experiencing tourist season extension and mitigation of the effects of depopulation and economic degradation of rural areas, primarily due to the foundation of the special multisectoral institution, Scotland's Highlands and Islands Development Board (Lukić, 2000). For Croatia, which only has $0.1 \%$ of its family farms included in rural tourism $^{4}$ (Austria 8\%, France 6\%, Scotland 3\%) (Baćac, 2011), such development orientation strategy is of great importance.

A unique model of agrotourism development on a European scale does not exist and therefore one can identify different sorts of national organisations: governmental, non-governmental, professional organisations and interest groups. Not all those organisations operate on a national scale, but they do develop regional or local branches which give them greater strength, as local organisations know best the localities and their needs (Jelinčić, 2007). For example, when it comes to agrotourism promotion, Italy serves as a good model with several active organisations, among which Agriturist, founded in 1965, is the oldest and most systematically organised national society, having as its goal promotion and protection of national and regional eno-gastronomic products, ambience, landscapes and rural culture. Italy is also one of the rare countries having a clear law on a country level (Jelinčić, 2007). Austrian farm tourism has a $1 / 6$ share in the total overnight stays (170 000 beds). Prices are moderate ( $€ 25$ per night) and generate an annual profit of $€ 25000$ per farm. It is organised into the society called Farm Holidays, which was founded in order to present clearly and precisely the diverse offer (Breiling, 2005). In France, the national Gites de France society combines a diverse supply of agrotourism. Direct sales of Gittes de France amount nowadays to $€ 350$ Million, that is $€ 600$ Million of income for the local economy, of which $€ 180$ Million are being reinvested into the reconstruction of architectural heritage. In Great Britain, Farm Stay UK is an example of an active organisation, a consortium owned by farmers, founded
Primjeri brojnih europskih zemalja, npr. Austrije i Škotske, potvrđuju navedene tvrdnje da se agroturizmom može postići revitalizacija ruralnih područja, ali isto tako i ublažavanje sezonskoga karaktera turizma. Tako u Škotskoj od osamdesetih godina 20. stoljeća dolazi do produljenja turističke sezone i ublažavanja efekata depopulacije i gospodarskog propadanja rurisa ponajprije zahvaljujući osnutku posebnoga međusektorskog tijela, Škotske razvojne uprave za gorsko područje i otoke (Scotland's Highlands and Islands Development Board) (Lukić, 2000). Za Hrvatsku, u kojoj se samo $0,1 \%$ poljoprivrednih domaćinstava bavi seoskim turizmom ${ }^{4}$ (Austrija $8 \%$, Francuska $6 \%$, Škotska $3 \%$ ) (Baćac, 2011), takvo je razvojno usmjerenje strateški važno.

Jedinstven model razvoja agroturizma na europskoj razini ne postoji te tako nailazimo na nacionalne organizacije različita karaktera: vladina, nevladina, profesionalnog ili interesnog povezivanja. Gotovo sve te organizacije ne djeluju samo na nacionalnoj razini već se razvijaju i u okviru regionalnih ili lokalnih podružnica, što im daje veću snagu jer upravo lokalna organizacija najbolje poznaje lokalitet i njegove potrebe (Jelinčić, 2007). Primjerice u promidžbi agroturizma u Italiji djeluje nekoliko organizacija, od kojih je najstarija i najsustavnije organizirana nacionalna udruga Agriturist, osnovana još 1965. s ciljem promidžbe i zaštite nacionalnih proizvoda i regionalnih enogastronomskih proizvoda, ambijenta, krajolika i ruralne kulture. Italija je i jedna od rijetkih zemalja koja posjeduje jasan zakon na državnoj razini (Jelinčić, 2007). U Austriji turizam na farmama ima udio od šestine ukupnih noćenja (170.000 kreveta). Umjerenih je cijena (25 eura noćenje) i donosi promet od 25.000 eura po farmi godišnje. Organiziran je u udrugu Farm Holidays, koja je osnovana kako bi jasno i precizno predstavila raznoliku ponudu (Breiling, 2005). U Francuskoj nacionalna udruga Gîtes de France ujedinjuje raznovrsnu ponudu seoskog turizma. Izravna prodaja te udruge danas iznosi 350 milijuna eura, odnosno 600 milijuna eura prihoda lokalnom gospodarstvu, od čega se 180 milijuna eura ulaže u obnovu arhitektonske baštine. U Velikoj Britaniji vrlo je aktivna organizacija Farm Stay UK, konzorcij u vlasništvu

4 In this context, rural tourism is a synonym for agrotourism, although its meaning varies from source to source.

4 U ovom kontekstu pojam seoski turizam istoznačnica je za agroturizam iako mu značenje inače varira od izvora do izvora. 
with the primary goal of effective promotion of accommodation offered by its members, with the aim of increasing tourist nights and income (Jelinčić, 2007). It can be seen that agrotourism has been recognised as an important factor of development and survival of typical family farms and development of rural local economies in many European countries.

\section{Research aims and hypotheses}

The primary aim of this paper is to detect the conditions, role and opportunities for the development of agrotourism in Littoral Croatia and identify its role in tourist season extension from the perspective of carriers of that particular type of tourist activity. On the basis of the analysed literature and results of the research, suggestions for development of agrotourism in the future will be laid out, which could become a foundation of the new development strategies. The topic is strategically very important for Croatia, having in mind the importance of tourism in the gross value added of the country ${ }^{5}$, the high percentage of rural areas in the total surface area of the country, as well as ongoing neglect of this aspect of tourism development. Adequate valorisation of the rural space gives rise not only to the possibility of mitigating the seasonality factor, but also building the preconditions necessary for its realisation thorough revitalisation. Based on the previous knowledge of the research subject of this paper, it was possible to list the following hypotheses:

H 1 - The role of agrotourism in tourist season extension in Croatia is still marginal due to its poor degree of development and the fact that this type of tourism is unrecognisable; however, under adequate conditions, this role could be significantly higher.

H 2 - Littoral counties are characterised by the higher degree of development of RTFFs.

H 3 - Tourism seasonality is pronounced to a lesser extent in the interior of Littoral Croatia as compared to the coast.

H 4 - The main reasons for insufficiently developed agrotourism in general and outside the summer season are inadequate intervention by the state and administrative institutions and the legislative barriers. farmera osnovan s primarnim ciljem učinkovite promidžbe smještaja koji nude njezini članovi kako bi se povećali broj noćenja i prihodi (Jelinčić, 2007). Dakle jasno je da je agroturizam u nizu europskih zemalja prepoznat kao važan čimbenik razvoja i opstanka klasičnih seoskih gospodarstava te razvoja lokalnih ekonomija ruralnih sredina.

\section{Ciljevi rada i hipoteze}

Cilj je rada detektirati stanje, ulogu i mogućnosti razvoja agroturizma u Primorskoj Hrvatskoj te utvrditi mogućnosti njegove funkcije produljenja turističke sezone, gledano iz perspektive nositelja takva oblika turističke djelatnosti. Potom će se na osnovi rezultata istraživanja i analizirane literature iznijeti prijedlozi razvoja agroturizma u budućnosti, koji mogu postati temeljom novih razvojnih strategija. Tema je za Hrvatsku strateški važna imajući u vidu važnost turizma u ukupnom dohotku ${ }^{5}$, visoki udio ruralnog prostora u ukupnoj površini države te kontinuitet zapostavljanja njegova razvoja. Adekvatnom valorizacijom ruralnog prostora otvara se ne samo mogućnost ublažavanja sezonalnosti već i stvaranja pretpostavki za realizaciju njegove sveobuhvatne revitalizacije. $\mathrm{Na}$ osnovi prethodnog poznavanja predmeta istraživanja rada moguće je postaviti sljedeće radne hipoteze:

H 1 - Uloga agroturizma u produljenju turističke sezone u Hrvatskoj zasad je marginalna zbog slabe razvijenosti i neprepoznatljivosti tog oblika turizma, ali u odgovarajućim uvjetima može biti znatno veća.

H2 - Većim razvojem TSOG-ova u Hrvatskoj ističu se primorske županije.

H 3 - Sezonalnost turizma manje je izražena u unutrašnjosti Primorske Hrvatske nego na obalnom prostoru.

H 4 - Glavni razlozi nedovoljne razvijenosti agroturizma općenito i izvan ljetne sezone jesu nedovoljan angažman državnih ili upravnih tijela i pravne prepreke.
M. Košak,

K. Lugomer

The role of agrotourism in tourist season extension in

Littoral Croatia

Agroturizam u funkciji produljenja turističke sezone

Primorske Hrvatske

5 It was determined that tourist expenditure in 2005 in Croatia generated HRK 33.3 Billion or $14.7 \%$ of the total gross value added.

5 Utvrđeno je da je 2005. godine turistička potrošnja u Republici Hrvatskoj generirala 33,3 milijarde kuna ili 14,7 \% ukupne bruto dodane vrijednosti. 
GEOGRAFSKI

GLASNIK

77/2,141-168 (2015.)
H 5 - RTFFs in Littoral Croatia are mainly final destinations, which makes agrotourism independent of the flow of tourists that are present on the coast in a given period.

H 6 - The young population is mostly uninterested in the continuation of the managing their parents' family farms, which raises doubts about the survival of agrotourism in the future.

The listed hypotheses will be tested throughout the research procedure and generated results will serve as a basis for the final conclusions.

\section{Respondents and methodology}

For the purposes of this paper, the researched area of Littoral Croatia has been divided into the sub-regions defined as counties and having a coastline on the Adriatic Sea, from which lower-division administrative-territorial units (towns and municipalities) located outside the boundaries of Littoral Croatia have been removed (Fig. 1). The area defined in this way encompasses 201 administrative-territorial units, out of which $21 \%$ (42) make up the towns and municipalities in which this research took place.

The central part of the paper methodology encompassed telephone surveys of the carriers of the RTFFs in Littoral Croatia. The survey was conducted by using the purpose sampling method. Only those family farms that provided accommodation services were contacted, as the possibility of an overnight stay makes them relevant for tourist season extension ${ }^{6}$.

The phone survey entailed 55 RTFFs in Littoral Croatia and it was supplemented by fieldwork making use of the same survey, and informal research conversation with RTFF owners. Fieldwork was conducted in order to explore better the situation regarding agrotourism in Littoral Croatia and it took place on 26 April 2013, encompassing two RTFF owners in Zadar County and one in Šibenik-Knin County, who had not previously participated in the telephone survey. Owing to the fieldwork, the total number of surveyed owners rose to 58 . They were
H 5 • TSOG-ovi u Primorskoj Hrvatskoj uglavnom su krajnja turistička odredišta, što agroturizam čini neovisnim o obujmu turista koji su u određenom razdoblju smješteni na obali.

H 6 • Mlado stanovništvo većim je dijelom nezainteresirano za nastavak obiteljske djelatnosti agroturizma, što dovodi opstanak te djelatnosti u pitanje.

Navedene će hipoteze biti provjerene istraživačkim postupkom te će se iz dobivenih rezultata izvesti zaključci.

\section{Ispitanici i metode rada}

$\mathrm{Za}$ potrebe rada istraživani prostor Primorske Hrvatske podijeljen je na subregije, koje se definiraju kao županije s izlazom na Jadransko more, iz kojih su izuzete administrativno-teritorijalne jedinice (upravni gradovi i općine) smještene izvan granica Primorske Hrvatske (sl. 1). Tako definirani prostor obuhvaća ukupno 201 administrativno-teritorijalnu jedinicu u čijih je $21 \%$ (42) upravnih gradova i općina provedeno istraživanje.

Središnji dio metodologije rada bilo je telefonsko anketno istraživanje nositelja TSOG-ova na prostoru Primorske Hrvatske. Anketiranje je provedeno metodom namjernog uzorka te su anketirana samo gospodarstva koja pružaju uslugu smještaja, pa su zbog postojanja mogućnosti noćenja relevantna za produljenje turističke sezone ${ }^{6}$.

Telefonskim je anketiranjem obuhvaćeno 55 TSOG-ova s prostora Primorske Hrvatske. Telefonsko anketiranje dopunjeno je terenskim istraživanjem metodom ankete i slobodnoga istraživačkog razgovora s nositeljima TSOG-ova. Terensko istraživanje provedeno je u svrhu boljeg upoznavanja stvarnog stanja u agroturizmu Primorske Hrvatske. Istraživanje je provedeno 26. travnja 2013. te je obuhvatilo dva nositelja TSOG-a iz Zadarske i jednoga iz Šibensko-kninske subregije koji nisu sudjelovali u telefonskom anketiranju. Terenskim istraživanjem upotpunjen je broj anketiranih ispi-

6 This statement is supported by the fact that tourism offering accommodation, i.e. overnight stays, is the only possibility for the prolongation of the total stays of guests in the rural areas and tourist season extension (Demonja i Ružić, 2010).

6 Takvu tvrdnju opravdava činjenica da je boravišni turizam (za koji je potrebna usluga noćenja) jedina mogućnost za produljivanje boravka gostiju na selu i sezone (Demonja i Ružić, 2010) 


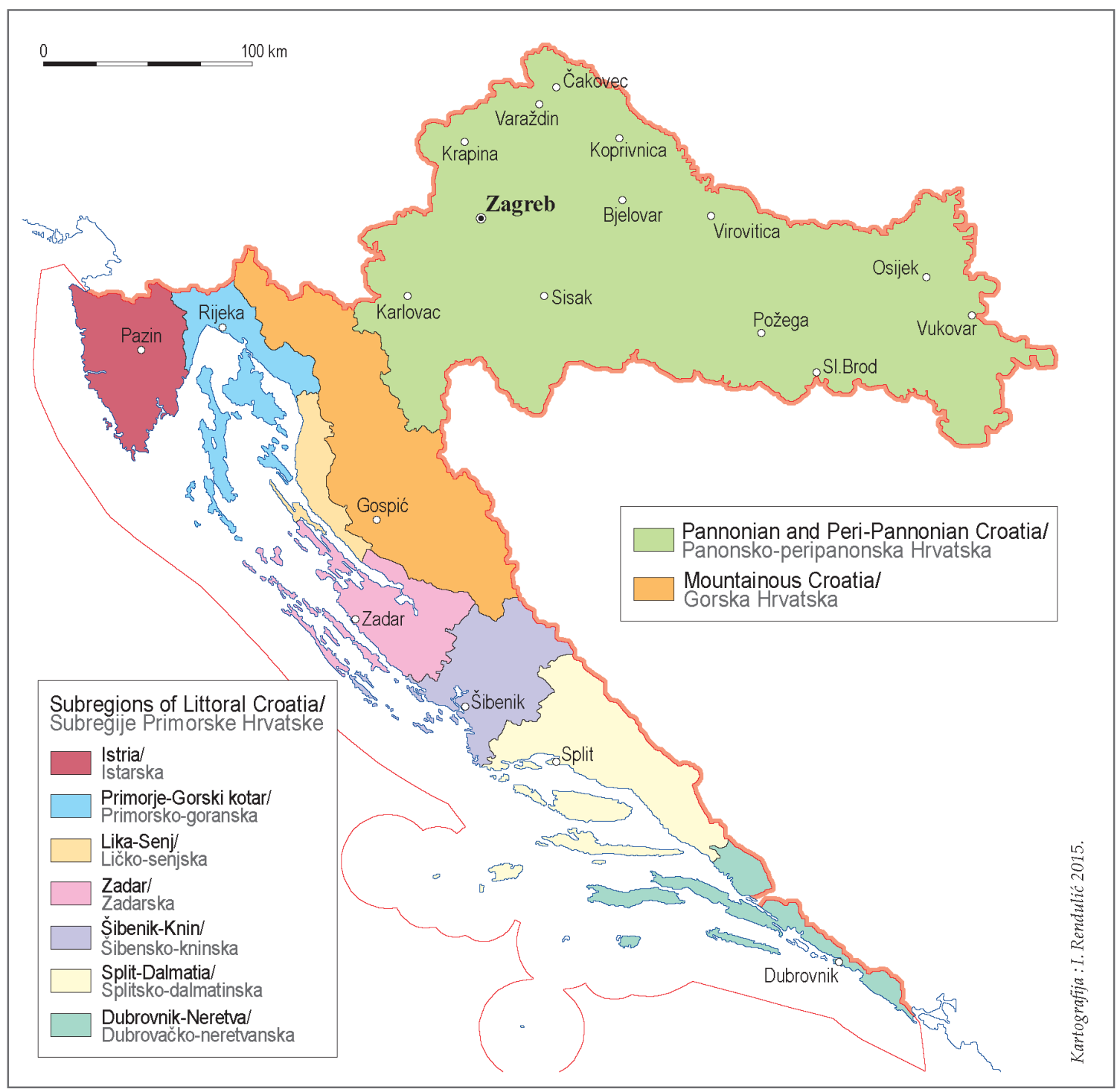

Fig. 1 Sub-regions in Littoral Croatia as the research area

SI. 1. Subregije Primorske Hrvatske kao prostor istraživanja

Source: Curić et. al., 2013

Izvor: prema Curić i dr., 2013.

scattered throughout 39 different towns/municipalities of Littoral Croatia. The sample is considered to be relevant as it makes up $84.1 \%$ of the $69 \mathrm{RTFF}$ owners $^{7}$ offering accommodation services in Littoral Croatia in 2012, i.e. $42.3 \%$ of the total 137 RTFFs in the same area in the same year.
M. Košak,

K. Lugomer

The role of agrotourism in tourist season extension in

Littoral Croatia

Agroturizam u funkciji produljenja turističke sezone

Primorske Hrvatske

7 According to the data obtained from the Departments of Tourism of the Chambers ofEeconomy of the individual counties, the total number amounted to 77; however, during the survey process it was found that some of the RTFFs had stopped operating in the meantime or did not offer accommodation services, although the supplied data suggested otherwise, or they had started operating as agrotourism units from the beginning of this year (2013).

7 Prema podacima odjelâ za turizam županijskih komora, ukupni je broj zapravo bio 77, no tijekom anketiranja ustanovljeno je da su neki TSOG-ovi u međuvremenu prestali s radom ili ne pružaju uslugu smještaja iako je u dobivenim podacima stajalo suprotno ili se počinju baviti agroturizmom tek od ove godine (2013). 
GEOGRAFSKI

GLASNIK

77/2, 141-168 (2015.)
When it comes to the gender structure of the RTFF owners ${ }^{8}$, men prevail with $73.3 \%$. The corresponding age structure reveals that owners aged 40 44 and 50 - 54 dominate, while the average age of all the surveyed owners equals 44.93 years.

The educational profile of RTFF owners shows that secondary school education prevails with $73.3 \%$. About $12 \%$ have a university degree, a non-university level college degree is held by $10 \%$ of the owners, while the remaining $5 \%$ make up owners with primary school being their highest level of education obtained.

Besides the previously mentioned methods, the paper incorporated methods of descriptive statistics with emphasis on the calculation of the coefficient of variation, serving as a descriptive statistic relevant for the determination of the degree of seasonality in the different municipalities of Littoral Croatia.

Statistical data used in the paper were acquired from the Departments of Tourism of the Chambers of Economy of the individual counties of Croatia. This was due to the fact that data obtained from the Ministry of Tourism and the Central Office of the Croatian Chamber of Economy were out of date. Through research-focused conversation with the secretary of the Community of Rural Tourism (from 2015, the Community of Family Tourism) of the Croatian Chamber of Economy, Lidija Mišćin, secretary of the Ministry of Tourism, Matilda Đurek, and Nikola Cinkopan of the Department of Tourism of Pula County Chamber, causes for the lack of the most recent data have been investigated, It was found that poor coordination between the Croatian Chamber of Economy and the Ministry of Tourism on the one hand, and Departments of Tourism of the Chambers of Economy of the individual counties on the other, was the primary reason for the poor quality of data available for the analysis.

Part of the data used in this article was obtained from the Croatian Bureau of Statistics' specific publications that will be cited throughout the paper.
TSOG-ova na istome prostoru iste godine.

U spolnoj strukturi nositelja ${ }^{8}$ TSOG-ova prevladavaju muškarci sa 73,3 \%. U dobnoj strukturi nositelja prema petogodišnjim dobnim skupinama najviše ih je u dobi $40-44$ godine te $50-54$ godine, dok je prosječna dob svih nositelja 44,93 godine.

U obrazovnoj strukturi prevladavaju ispitanici srednje stručne spreme (73,3\%). Visoku stručnu spremu ima $12 \%$, višu stručnu spremu samo $10 \%$ nositelja, a preostalih 5 \% čine nositelji sa završenom osnovnom školom.

Osim spomenutih metoda u radu je upotrijebljena i metoda deskriptivne statistike s naglaskom na izračun koeficijenta varijacije kao mjere disperzije relevantne za određivanje stupnja sezonalnosti u pojedinim općinama Primorske Hrvatske.

Statistički podaci upotrijebljeni u radu dobiveni su od odjelâ za turizam županijskih gospodarskih komora jer su podaci koje su ustupili Ministarstvo turizma i centralni ured Hrvatske gospodarske komore bili neažurirani. Slobodnim istraživačkim razgovorom s tajnicom Zajednice ruralnog turizma (od 2015. Zajednica obiteljskog turizma) Hrvatske gospodarske komore Lidijom Mišćin, tajnicom Ministarstva turizma Matildom Đurek te Nikolom Cinkopanom iz Odjela za turizam Županijske komore Pula utvrđeno je da je uzrok neažuriranosti slaba koordinacija Hrvatske gospodarske komore i Ministarstva turizma s odjelima za turizam županijskih gospodarskih komora

Dio podataka upotrijebljenih u radu preuzet je sa stranica Državnog zavoda za statistiku, iz publikacija koje će u radu biti spomenute.

\footnotetext{
8 When it comes to representing age, gender and educational composition of the RTFF owners, the base for comparison was the total number of owners (60). This number is not equal to the number of respondents surveyed in the research, because two of the surveyed RTFFs had two owners.

8 U prikazivanju dobne, spolne i obrazovne strukture nositelja TSOG-ova pomoću relativnih brojeva, baza usporedbe jest ukupni broj nositelja (60). Taj
} broj nije jednak broju ispitanika zbog toga što dva anketirana TSOG-a imaju dva nositelja. 


\section{Number of RTFFs}

According to the most recent complete official data of the Croatian Chamber of Economy, there are 379 RTFFs registered in Croatia, of which those located in Littoral Croatia make up 65.7\% (Demonja and Ružić, 2010) (Fig. 2). The largest number of RTFFs can be

\section{Broj TSOG-ova}

Prema posljednjim cjelovitim službenim podacima Hrvatske gospodarske komore, u Republici Hrvatskoj registrirano je ukupno 379 TSOG-ova, od čega ih je u Primorskoj Hrvatskoj 65,7 \% (Demonja i Ružić, 2010) (sl.2). Najveći je broj TSOG-

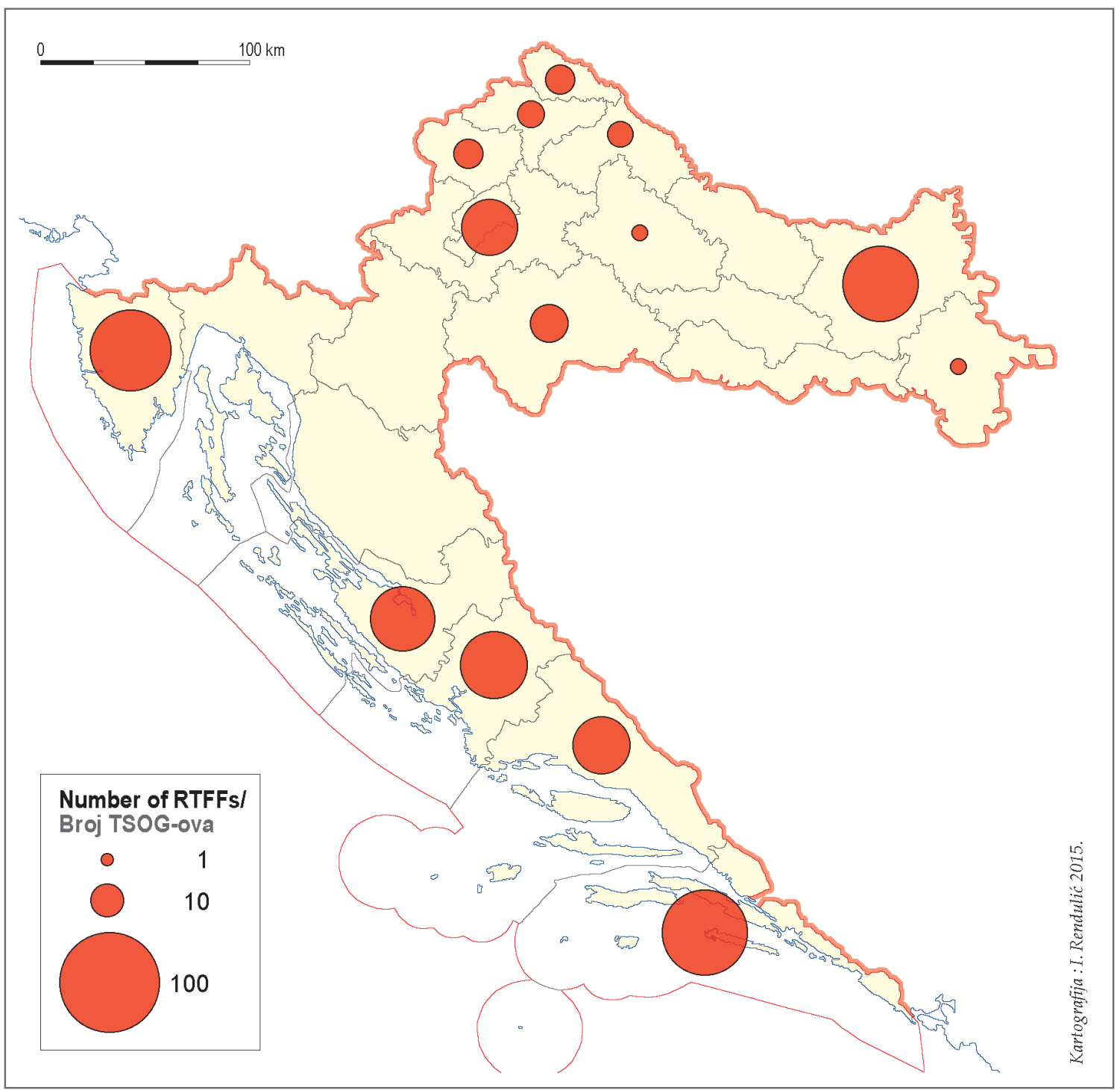

Fig. 2 RTFFs in Croatian counties in 2007

SI. 2. Broj TSOG-ova u županijama Republike Hrvatske 2007. godine

Source: Demonja and Ružić, 2010

Izvor: prema Demonja i Ružić, 2010. 
GEOGRAFSKI

GLASNIK

77/2, 141-168 (2015.) found in the Dubrovnik-Neretva County (70) and Istria County (64). In Highland Croatia there are no registered RTFFs, and in Pannonian Croatia, Osijek-Baranja County (56) and Zagreb County (30) dominate. The domination of Littoral Croatia in the number of RTFFs can be confirmed by brief inspection of Figure 2. Exceptions to this are Lika-Senj County, which is only to a very small extent located within the limits of the Littoral Croatia, and the Primorje-Gorski Kotar County. Those two counties did not have any RTFFS registered back in 2007.

Analysis of spatial distribution of RTFFs shows that rural areas without RTFFs are at the same time areas in Croatia with the most pronounced socioeconomic problems. On the other hand, it has already been stressed that agrotourism is one of the fundamental factors of integral development of rural areas, whose systematic development contributes to the revitalisation of the regions experiencing severe socioeconomic decline.

\section{Seasonality in towns and municipalities of Littoral Croatia (2008 - 2012)}

Although previously reviewed literature did not contain papers making use of the coefficient of variation $^{9}$ as a statistical indicator of seasonality, we consider that it should be used in that context, as it successfully illustrates temporal dispersion of tourist arrivals and nights, as well as because of the simplicity of calculation and interpretation. For the purposes of this paper, tourism seasonality has been represented by the coefficient of variation of the tourist nights ${ }^{10}$ in towns and municipalities of Littoral Croatia in the period from 2008 to $2012^{11}$. Its value rarely exceeds 100\% (Papić, 2010), but in our case such values were exceptionally frequent. This is just additional confirmation of the very pronounced seasonality of tourism in the whole of Littoral Croatia. However, significant regional differences can also be detected. ova zabilježen u Dubrovačko-neretvanskoj (70) i Istarskoj županiji (64). U Gorskoj Hrvatskoj nema registriranih TSOG-ova, a u Panonsko-peripanonskoj Hrvatskoj prednjače Osječko-baranjska (56) i Zagrebačka županija (30). Dominaciju Primorske Hrvatske u broju TSOG-ova potvrđuje i sl. 2. Izuzetak su Ličko-senjska županija, koja se ionako samo malim dijelom nalazi u Primorskoj Hrvatskoj, te Primorsko-goranska županija. U njima 2007. godine nema registriranih TSOGova.

Promatranjem prostorne distribucije lako je zaključiti da su ruralni prostori bez TSOG-ova ujedno i prostori s najizraženijim socijalno-ekonomskim problemima u Hrvatskoj. Istovremeno je poznato da je agroturizam jedan od temeljnih nositelja turizma kao čimbenika integralnog razvoja ruralnih područja, čiji sustavan razvoj pridonosi revitalizaciji problemskih prostora.

\section{Jačina sezonalnosti u gradovima i općinama Primorske Hrvatske 2008. - 2012.}

Iako u dosadašnjoj literaturi nisu pronađeni radovi u kojima se upotrebljava koeficijent varijacije kao statistički pokazatelj jačine sezonalnosti, smatramo kako ga je u tom kontekstu opravdano upotrebljavati zbog ilustrativnosti vremenske disperzije turističkih dolazaka i noćenja te jednostavnosti izračuna i interpretacije. $Z$ a potrebe ovoga rada sezonalnost turizma prikazana je koeficijentom varijacije turističkih noćenja ${ }^{10} \mathrm{u}$ gradovima i općinama Primorske Hrvatske od 2008. do $2012^{11}$. Njegova vrijednost rijetko je veća od 100 \% (Papić, 2010), no u našem su slučaju takve vrijednosti bile izrazito česte. To je samo dodatna potvrda vrlo jake sezonalnosti turizma u cijeloj Primorskoj Hrvatskoj. No unatoč tomu na prostoru Primorske Hrvatske postoje i značajne regionalne razlike.

9 The coefficient of variation is a relative method of dispersion that is defined as a ratio of standard deviation and the mean of observed values.

9 Koeficijent varijacije jest relativna mjera disperzije koja se definira kao omjer standardne devijacije i aritmetičke sredine promatranih vrijednosti..

10 We did not take into account the variation of tourist arrivals due to the previously mentioned fact that nights are a better indicator of tourist development and the possibility of tourist season extension.

10 Nismo uzimali u obzir varijaciju turističkih dolazaka zbog već navedene činjenice da su noćenja bolji indikator turističke razvijenosti i mogućnosti produljenja turističke sezone.

11 In order to calculate the variation coefficient, we used the data of the Central Bureau of Statistics, but it should be noted that for a large number of municipalities data are confidential and unavailable.

$11 \mathrm{Za}$ izračunavanje koeficijenta varijacije upotrijebljeni su podaci Državnog zavoda za statistiku, ali valja napomenuti da za veliki broj općina podaci zbog tajnosti nisu objavljeni pa se zbog nedostupnosti oni nisu mogli uzeti u obzir. 
Having in mind that the coefficient of variation is the indicator of seasonality in this case, spatial distribution of the coefficient of variation of tourist nights in Croatia between 2008 and 2012 shows a fundamental spatial pattern: Seasonality is to a lesser extent pronounced in the interior of Littoral Croatia, with particular emphasis on northern and central Istria, the urban agglomeration of Rijeka, hinterland of Šibenik and parts of Split-Dalmatia and Dubrovnik-Neretva County (the Sinjsko, Imotsko, Vrgoračko polje and Konavle region) (Fig. 3). At the same time, the coast-
Imajući na umu da je koeficijent varijacije ovdje pokazatelj sezonalnosti, iz prostorne raspodjele koeficijenta varijacije turističkih noćenja u Hrvatskoj 2008. - 2012. proizlazi temeljna prostorna zakonitost: sezonalnost je slabije izražena u unutrašnjosti Primorske Hrvatske, s naglaskom na sjevernu i srednju Istru, riječku aglomeraciju, prostor šibenskog zaleđa te dijelove pograničnog prostora Splitsko-dalmatinske i Dubrovačko-neretvanske županije (Sinjsko, Imotsko i Vrgoračko polje te Konavle) (sl. 3). Istovremeno, priobalje i otoci imaju
M. Košak, K. Lugomer

The role of agrotourism in tourist season extension in

Littoral Croatia

Agroturizam u funkciji produljenja turističke sezone

Primorske Hrvatske

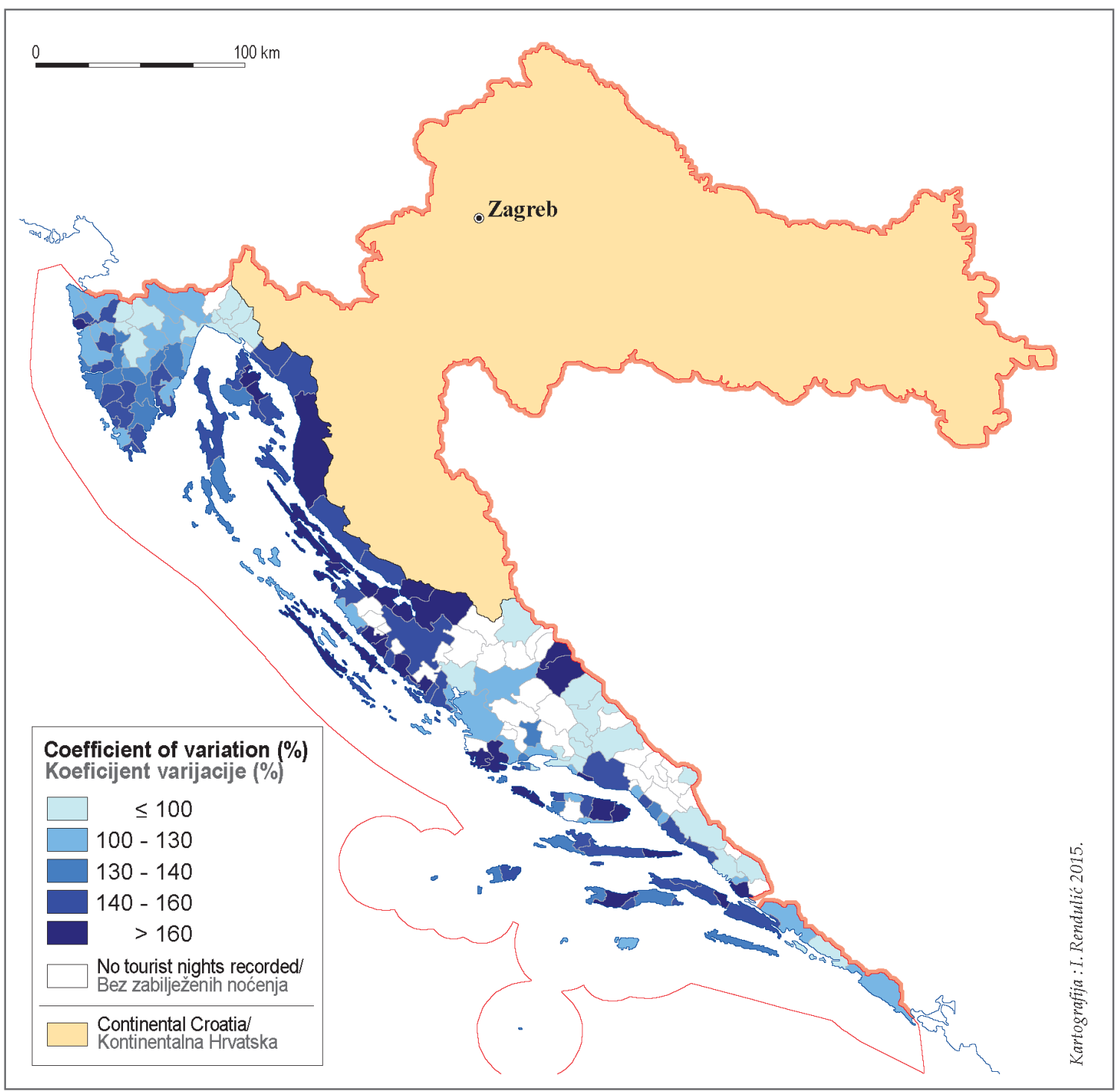

Fig. 3 Spatial distribution of seasonality in cities and municipalities of the Littoral Croatia from 2008 to 2012

SI. 3. Prostorna raspodjela jačine sezonalnosti u gradovima i općininama Primorske Hrvatske 2008. - 2012. godine

Source: Press and Statistical Reports, Tourism in 2008, 2009, 2010, 2011, 2012, Croatian Bureau of Statistics Izvor: prema: Priopćenja i statistička izvješća - Turizam u 2008., 2009., 2010., 2011. i 2012. godini, Državni zavod za statistiku. 
GEOGRAFSKI

GLASNIK

77/2, 141-168 (2015.) line and islands are associated with higher seasonality. Among the islands, Silba, Olib, Ist, Molat, Premuda and Škarda seem at first to be exceptions; however, that is due to the fact that they belong administratively to the City of Zadar, and not because of equally developed tourism throughout the calendar year.

After the coefficients of variations were calculated for the individual towns and municipalities, average values for the individual sub-regions of Littoral Croatia were calculated as well. The median was chosen as the most representative measure of central tendency, as certain municipalities had extreme values that would significantly impact the coefficient and therefore mask the real situation.

According to the coefficient of variation, seasonality is most highly pronounced in Zadar (179.1) and the Lika-Senj sub-region (168.4), while it is weakest in Istria (130.9) and the Dubrovnik-Neretva sub-region (134.1).

The next section of the paper will present the results of telephone and field survey, which will, instead of general tourist flows, focus on agrotourism and the its possible role in the reduction of seasonality.

\section{RTFFs supply}

The amount and diversity of supply at the family farm along with the duration of the period during which RTFFs are open for tourists are important indicators of the degree of development of agrotourism and the duration of the tourist season.

When asked whether they predominantly buy food for tourism supply purposes or use food from their own sources, RTFF owners picked own sources in $74.1 \%$ of cases. The high prevalence of that response was expected because healthy and homemade food coupled with the idyllic rural ambience offered to visitors as a marketing product together make up one of the most recognisable features of agrotourism in general. Next, $17.2 \%$ of the respondents answered that they buy and use their own food in approximately similar amounts, while $8.6 \%$ of the respondents mostly buy the food subsequently served to their guests.

Furthermore, in order to find out how pronounced izraženiju sezonalnost. Među otocima su naizgled iznimka Silba, Olib, Ist, Molat, Premuda i Škarda, no to je posljedica njihove administrativne pripadnosti Gradu Zadru i s tim povezanim pripadanjem istome statističkom razredu, a ne stvarne razvijenosti turizma tijekom cijele godine.

$\mathrm{Na}$ temelju dobivenih koeficijenata varijacije za pojedine gradove i općine, izračunali smo srednju vrijednost za pojedine subregije Primorske Hrvatske. Kao srednja vrijednost uzet je medijan jer su u pojedinim općinama prisutne ekstremne vrijednosti, koje bi bitno modificirale koeficijent i time narušile vjernost prikaza prostorne stvarnosti.

Kako pokazuje koeficijent varijacije, jačina sezonalnosti najizraženija je u Zadarskoj $(179,1)$ i Ličko-senjskoj $(168,4)$ subregiji, dok je najslabija u Istarskoj $(130,9)$ i Dubrovačko-neretvanskoj subregiji $(134,1)$.

U nastavku rada izložit ćemo rezultate telefonskog i terenskog anketnog istraživanja, koji ce se umjesto na općenita turistička kretanja fokusirati na agroturizam i njegove mogućnosti ublažavanja sezonalnosti.

\section{Ponuda TSOG-ova}

Količina i raznovrsnost ponude na seljačkom gospodarstvu zajedno s trajanjem rada (otvorenost TSOG-ova turistima tijekom cijele godine) važni su indikatori razvijenosti agroturizma i trajanja turističke sezone.

Na pitanje kupuju li većinom hranu za potrebe turizma ili većinom upotrebljavaju hranu iz vlastitih izvora, vlastiti su izvori bili odgovor u 74,1\% slučajeva. Visoka zastupljenost tog odgovora očekivana je zbog toga što se kao prepoznatljivo obilježje agroturizma često izdvaja upravo zdrava i domaća hrana s ciljem stvaranja idiličnoga seoskog ugođaja koji se nudi potencijalnim turistima kao marketinški proizvod. Nadalje, 17,2 \% ispitanika odgovorilo je da u podjednakim količinama kupuje odnosno upotrebljava hranu iz vlastitih izvora, a preostalih 8,6 \% da većinom kupuje.

Kako bismo doznali izraženost ponude izvan ljetne sezone te odredili kakvi su uvjeti za produ- 
supply is outside the summer season and determine the conditions for tourist season extension, we asked RTFF owners what their supply entailed during the non-summer months (Tab. 1). The responses accommodation and food were neglected in this case, as those amenities can be found at all the RTFFs surveyed, while cases where accommodation and food were the only elements of tourist supply were joined into the special category. The final result showed that the tourist supply of RTFFs in Littoral Croatia mainly encompass hunting and participation in harvests, and recreation (hiking, horse riding, cycling, using the sports terrains). It should be emphasised that these results are largely influenced by the Istria sub-region ( 24 out of 31 responses related to hunting and harvesting; 17 out of 29 responses related to recreation). ljenje turističke sezone, nositelje TSOG-ova pitali smo što obuhvaća njihova ponuda izvan ljeta (tab. 1). Pritom smo zanemarili odgovore smještaj i prebrana jer su to sadržaji koje imaju svi anketirani TSOG-ovi, a za slučajeve u kojima ponudu čine isključivo smještaj i prehrana formirali smo posebnu kategoriju. Kao rezultat dobili smo da u ponudi dominiraju lov i berba plodova te rekreacija (planinarenje, jahanje, biciklizam, korištenje sportskim terenima). Valja naglasiti kako te rezultate uvelike ponderira Istarska subregija ( 24 od 31 odgovora vezanog uz lov i berbu plodova, 17 od 29 vezanih uz rekreaciju).

Istovremeno, u kategoriji samo prehrana i smještaj Istarska subregija sudjeluje sa samo tri od ukupno četrnaest odgovora, dok se čak šest od četrnaest od-

Tab. 1 Tourist attraction of RTFFs in the off-season

Tab. 1. Ponuda TSOG-ova izvan ljetne sezone

\begin{tabular}{|l|c|}
\hline \multicolumn{1}{|c|}{$\begin{array}{c}\text { Elements / } \\
\text { Elementi ponude }\end{array}$} & $\begin{array}{c}\text { Frequency (\%)/ } \\
\text { Učestalost } \\
\text { pojavljivanja (\%) }\end{array}$ \\
\hline Hunting and fruit picking / Lov i berba plodova & 28,5 \\
\hline Recreation / Rekreacija & 26,6 \\
\hline Only accommodation and food / Samo smještaj i prehrana & 12,8 \\
\hline Excursions / Izleti & 11,0 \\
\hline Culinary and craft shops / Kulinarske i obrtničke radionice & 10,1 \\
\hline Organization of social gatherings / Organizacija društvenih okupljanja & 7,3 \\
\hline $\begin{array}{l}\text { Other (logging, sightseeing tours, animal parks...) / } \\
\text { Ostalo (sječa drva, panoramski letovi, uživanje u životinjskom parku...) }\end{array}$ & 3,7 \\
\hline Total / Ukupno & 100,0 \\
\hline
\end{tabular}

At the same time, in the only food and accommodation category, the Istria sub-region participated with only 3 out of 14 responses, while 6 out of 14 responses related to the Dubrovnik-Neretva sub-region. The view in literature is that the Dubrovnik-Neretva sub-region, after Istria, is the area with the most developed agrotourism in Croatia (Demonja and Ružić, 2010), but given data demonstrates that its supply is actually quite scarce. The fact that food and accommodation without any additional contents are present at $12.8 \%$ of all the surveyed family farms poses a serious warning, because departure from the sole oneday trip function of RTFFs towards agrotourism in the full sense requires wider and more diverse activities. It is
M. Košak,

K. Lugomer

The role of agrotourism in tourist season extension in

Littoral Croatia

Agroturizam u funkciji produljenja turističke sezone

Primorske Hrvatske govora odnosi na Dubrovačko-neretvansku subregiju. Za nju se u literaturi smatra da je nakon Istre područje najrazvijenijeg agroturizma u Hrvatskoj (Demonja i Ružić, 2010), no iz priloženih je podataka vidljivo da je i u njoj ponuda vrlo slaba. Podatak da samo prehranu i smještaj bez ikakvih dodatnih sadržaja od svih anketiranih gospodarstava ima njih $12,8 \%$ upućuje na to da je stanje alarmantno jer su za odmak od izletničke funkcije TSOG-ova prema agroturizmu u pravom smislu riječi potrebne šire i raznolikije aktivnosti. Valja istaknuti i kako se ostatak ponude naveden u tablici u većini slučajeva odnosi na Istru. 
GEOGRAFSKI

GLASNIK

77/2, 141-168 (2015.) worth mentioning that the rest of the supply shown in the table corresponds to the Istria sub-region in most of the cases.

Next, the answer to the question about plans for widening the supply during the non-summer months was affirmative in $71 \%$ of the cases, while the rest of the owners supported their negative answer by stressing the lack of finances and satisfaction with the current content available to the tourists. One case in the Šibenik-Knin County was particularly interesting because the reason for lack of plans for extension of the supply during the non-summer months was the fact that the maximum of tourist nights at that particular RTFF was normally not achieved during the summer, but rather during the winter (December and January) due to the popularity of hunting tourism.

When it comes to organisation of fieldtrips, about one half of the respondents (51.8\%) do not organise trips as part of their supply. The local percentage in the Istria sub-region amounts to $35.1 \%$, while the corresponding value for all the other sub-regions together equals $50.0 \%$. Organisation of fieldtrips is exceptionally rare in the Šibenik-Knin sub-region where 5 out of 6 respondents do not offer fieldtrips to their guests and the same is true for the Zadar sub-region, where the equivalent ratio equals 5 out of 7 .

Regarding the number of beds, 58 surveyed RTFFs have 578 beds in total, which leads to the average value of 9.97 beds per family farm in Littoral Croatia. The value varies - while this average value amounts to 10.72 in the Istria sub-region, the rest of the Littoral Croatia together has $9.21^{12}$ beds per family farm, on average.

The final important discovery regarding the tourist supply in RTFFs is that only $22 \%$ of the family farms is not open for business during the entire year. The most common reason mentioned for closing the doors of their family farms at a certain point during the year was the lack of guests. Among 13 RTFFs which are not open during the entire year, 5 of them start their tourist season in May and 6 of them close in September (Fig. 4). Only 2 farms start working in April, and by the end of October 4 farms close their doors. On average, the agrotour-
$\mathrm{Na}$ pitanje o proširenju ponude izvan ljeta oko $71 \%$ ispitanika odgovorilo je pozitivno, a oni koji to ne namjeravaju kao najčešće razloge navode nedostatak financijskih sredstava i zadovoljstvo trenutačnom širinom ponude. Zanimljiv je slučaj jednoga gospodarstva u Šibensko-kninskoj županiji gdje je kao razlog za neproširivanje ponude navedeno kako je problem turizam ljeti, a ne zimi te kako se maksimum noćenja ostvaruje u prosincu i siječnju zbog razvijenoga lovnog turizma.

Kada je posrijedi organizacija izletâ, oko polovine ispitanika $(51,8 \%)$ uopće je nema u svojoj ponudi. Pritom je u Istarskoj subregiji taj udio 35,1\%, a u ostalim subregijama zajedno 50,0\%. Organizacija izletâ posebna je rijetkost u Šibensko-kninskoj subregiji, gdje pet od šest ispitanika nema izlete u svojoj ponudi, a isto vrijedi i za Zadarsku subregiju, gdje je taj omjer pet od ukupno sedam.

Što se broja ležajeva tiče, anketiranih 58 gospodarstava raspolaže s ukupno 578 ležajeva, što u prosjeku čini 9,97 ležajeva na razini Primorske Hrvatske. U Istri je prosječni broj ležajeva 10,72, dok je u ostatku Primorske Hrvatske taj prosjek niži, $9,21^{12}$ ležaj. Za prihvat turista tijekom cijele godine nije otvoreno samo $22 \%$ ispitanika. Najčešći razlog koji ispitanici pritom ističu jest nedovoljan priljev gostiju. Među trinaest gospodarstava koja zatvaraju svoja vrata u neko doba godine, njih pet počinje turističku sezonu u svibnju, a šest završava s radom u rujnu (sl. 4). U travnju s radom počinju samo dva gospodarstva, a do kraja listopada s radom prestaju četiri gospodarstva. Prosječno gledano, sezona agroturizma u Primorskoj Hrvatskoj, promatrajući gospodarstva koja ne rade cijele godine, traje od svibnja do rujna.

12 Comparison of the Istria sub-region with the rest of Littoral Croatia is relevant because there were 29 participants from both sides. On the other hand, a comparison of average grades of all sub-regions would be impractical because the absolute number of respondents in some sub-regions is too small, despite the fact that a theoretically higher number could not be reached.

12 Usporedbu Istarske subregije i ostatka Primorske Hrvatske smatramo relevantnom jer u nju ulazi po 29 ispitanika s obje strane. S druge strane, usporedba prosječnih ocjena pojedinih subregija ne bi imala smisla jer je u pojedinim subregijama apsolutni broj ispitanika premali bez obzira na činjenicu da teoretski veći broj nije, s obzirom na temu i definirane ciljeve istraživanja, bilo moguće postići. 
ism season in Littoral Croatia lasts from May to September for those RTFFs that are not open throughout the entire year.

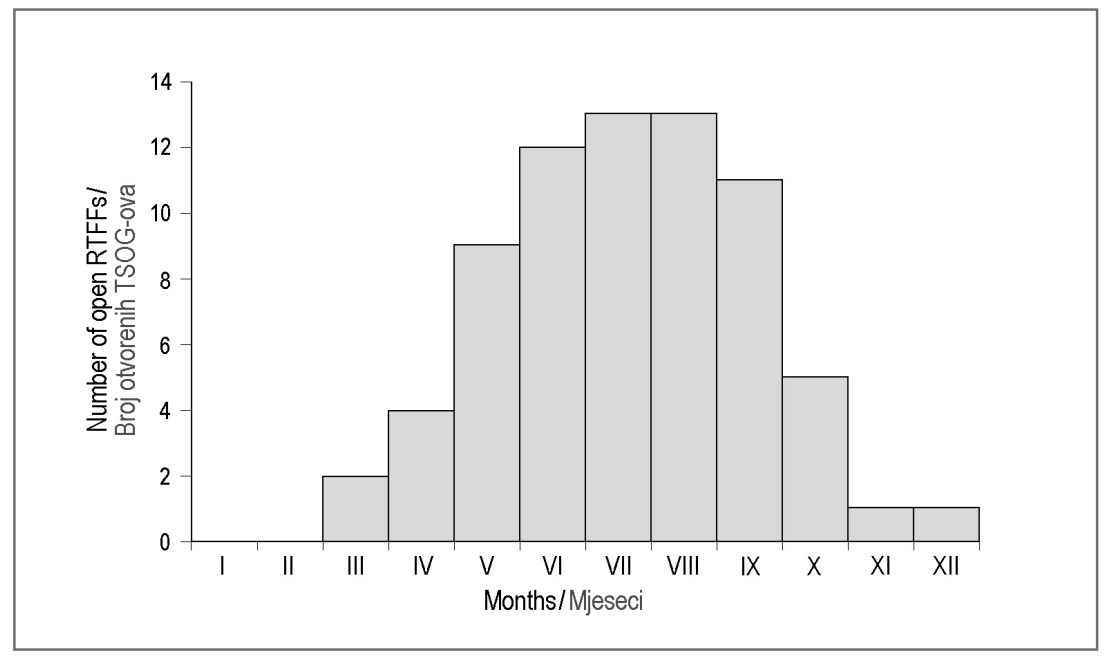

Fig. 4 Open RTFFs in certain months of the year

SI. 4. Broj otvorenih TSOG-ova u pojedinim mjesecima kroz godinu

\section{Demand in RTFFs}

After indicators of supply with implications on seasonality were analysed, the next step was to examine the indicators of demand with the goal of gaining a deeper insight into the situation and opportunities for tourist season extension. Among others, the question about the number of tourist arrivals and nights were asked, but not used in the analysis, because most of the respondents (87.9\%) did not know the exact data, making the comparison of the remaining few cases unsuitable.

The question Is your rural tourist family farm the final destination for the majority of your guests or just a passing destination during the vacation on the coast was used to determine dependence of the tourist flows on the coast. Mostly a passing destination was an option picked by $43.1 \%$ of the respondents, while $29.3 \%$ of the respondents claimed that their RTFF was mostly a final destination for their guests. In the Šibensko-kninska, Splitsko-dalmatinska and Dubrovnik-Neretva sub-regions, this relation is somewhat different since most of the tourists that visit RTFFs there pick them as their final destination although, in the case of the $\mathrm{Du}$ brovnik-Neretva sub-region, the difference between those two categories is minor.

\section{Potražnja u TSOG-ovima}

Nakon analize pokazateljâ ponude s implikacijama na sezonalnost, valja razmotriti i neke indikatore potražnje s ciljem cjelovitijeg prikaza stanja i mogućnosti produljenja turističke sezone. Među ostalima postavljeno je i pitanje o ostvarenim dolascima i noćenjima, koje nismo upotrijebili u analizi zbog toga što većina ispitanika $(87,9 \%)$ nije znala egzaktne brojčane podatke, pa usporedba preostaloga malog broja podataka ne bi imala smisla.

Odgovarajući na pitanje Je li većini posjetitelja vaše turističko seljačko obiteljsko gospodarstvo krajnja destinacija ili samo usputna destinacija tijekom boravka na obali, kojim se provjeravala ovisnost o obujmu turističkih kretanja na obali, 43,1 \% ispitanika opredijelilo se za opciju većinom usputna destinacija, a 29,3 \% za opciju većinom krajnja destinacija. U Šibensko-kninskoj, Splitsko-dalmatinskoj i Dubrovačko-neretvanskoj subregiji taj je odnos malo drugačiji, pa većinu čine turisti kojima su TSOG-ovi krajnja destinacija, s tim da je u Dubrovačko-neretvanskoj subregiji razlika između te dvije kategorije ispitanika neznatna. Zanimljivo je još razmotriti razlike između Istarske subregije i ostatka Primorske
M. Košak,

K. Lugomer

The role of agrotourism in tourist season extension in

Littoral Croatia

Agroturizam u funkciji produljenja turističke sezone

Primorske Hrvatske 
GEOGRAFSKI

GLASNIK

77/2,141-168 (2015.)
It is also interesting to see the differences between the Istria sub-region and the rest of Littoral Croatia. The Istria sub-region is more commonly associated with RTFFs being just a passing destination (Istria = $51.7 \%$, rest of the Littoral Croatia $=34.5 \%$ ).

The next question related to the demand included asking the respondents to name two months during which they had had a maximum of tourist nights over the past couple of years (Fig. 5). Four respondents did not know the answer and the remaining 54 gave 110 responses in tota ${ }^{13}$, of which $35(31.8 \%)$ were July and 33 (30.0\%) August, as one of the two months with a maximum of tourist nights. There were no maximums found in February, March, April or November, and the maximum of tourist nights in December and January was recorded by one family farm only, which has already been mentioned earlier in the section about supply. It should be noted that there is an asymmetry between maximums of tourist nights with respect to July and August as central months of the tourist season. That being said, June is more frequently a month with one of the two maximums of tourist nights as compared to September, and the same is true for the relation between May and October. It can be seen that the middle of the agrotourism season in Littoral Croatia is shifted towards spring.
Hrvatske. Naime u Istarskoj subregiji TSOG-ovi su češće samo usputna destinacija (Istra 51,7 \%, ostatak Primorske Hrvatske 34,5 \%).

U sljedećem pitanju vezanom uz potražnju ispitanike smo tražili da navedu dva mjeseca u kojima su prethodnih nekoliko godina najčešće ostvarivali maksimum noćenja (sl. 5). Četiri ispitanika nisu znala odgovor, a preostala 54 dala su ukupno 110 odgovora $^{13}$, od kojih se njih 35 (31,8 \%) odnosilo na srpanj, a $33(30,0 \%)$ na kolovoz kao jedan od dva mjeseca s najvećim brojem ostvarenih noćenja. U veljači, ožujku, travnju i studenome nema zabilježenih maksimuma noćenja, a u prosincu i siječnju to je zabilježilo samo jedno gospodarstvo koje se već spomenulo prilikom analize ponude. Valja još uputiti na asimetriju ostvarenih maksimuma noćenja s obzirom na srpanj i kolovoz kao središnje mjesece turističke sezone. Tako je lipanj češće mjesec s jednim od dva maksimuma noćenja od rujna, a isto vrijedi i za odnos svibnja i listopada. Time je težište sezone agroturizma u Primorskoj Hrvatskoj pomaknuto prema proljeću.

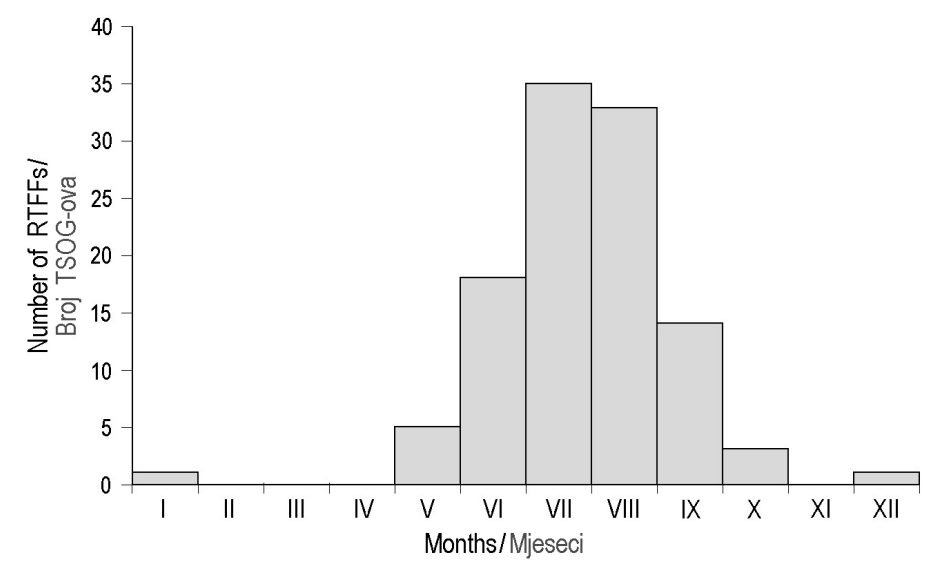

Fig. 5 Distribution of the usual maximum of overnight stas in RTFFs in certain months of the year SI. 5. Distribucija uobičajenih maksimuma ostvarenih noćenja u TSOG-ovima po mjesecima u godini

13 One respondent was unable to mention only two months because of maximum occupancy and the equal number of overnight stays in the period from June to September. In this case, four months were taken into consideration.

13 Jedan ispitanik nije bio u mogućnosti navesti samo dva mjeseca zbog maksimalne popunjenosti kapaciteta i time jednakog broja ostvarenih noćenja od lipnja do rujna, pa su u obzir uzeta sva četiri mjeseca. 


\section{Promotion and cooperation of RTFFs}

Promotion of RTFFs and co-operation with the commercial and political subjects we studied with questions about promotion on the Web, co-operation with travel agencies and with local and/or regional authorities in terms of their role in encouraging the development of agrotourism, led to the following information:.

$55.2 \%$ of respondents are promoted on the Web. Istria has a smaller percent, although the difference is not that significant (Istria $=51.7 \%$, the rest of the Littoral Croatia $=58.6 \%)$. All farmers that are promoted in Istria do that in multiple languages, unlike the rest of Littoral Croatia where that percent is something lower (82.4\%).

$58.6 \%$ of respondents co-operate with travel agencies. Co-operation is the weakest in the Zadar sub-region where only two of seven subjects collaborate with travel agencies. In the Dubrovnik-Neretva sub-region and throughout the Istria sub-region seven of nine subjects co-operate with travel agencies, and co-operation is more common than in the rest of Littoral Croatia by about $7 \%$. Since Istria and the Dubrovnik-Neretva sub-regions are the most developed in terms of agrotourism and, at the same time, co-operate most actively with travel agencies, we can say that this kind of co-operation is obviously essential for the significant tourist valorisation of rural areas. Co-operation with travel agencies also depends on accommodation. 19 of 24 RTFFs that do not co-operate with the agencies have less than the average number of beds (10) of all farms in Littoral Croatia). This is logical because they do not have accommodation for a potentially large numbers of guests.

The majority of respondents (75.9\%) claims that local or county authorities invest in the development of agrotourism. However, $78 \%$ of the total of 44 respondents believe that that is not enough, while $11 \%$ think that it is, because of the inability of providing major stimulus during the economic crisis. In cases where respondents indicated they have experienced some incentives in practice from the authorities, the question followed of what exactly the incentives had been. In most cases, they consisted of promotion (52.5\%), tax relief (15.2\%) and support for

\section{Promocija i suradnja TSOG-ova}

Izraženost promocije agroturizma te suradnje s komercijalnim i političkim subjektima istraživali smo pitanjem o postojanju promocije TSOG-ova na webu, suradnje s putničkim agencijama te suradnje s lokalnim i/ili županijskim vlastima u smislu njihova poticanja razvoja agroturizma.

$\mathrm{Na}$ webu se promovira 55,2 \% anketiranih TSOG-ova Primorske Hrvatske. Istra ima manji udio onih koji se promoviraju na internetu, iako ta razlika i nije toliko značajna (Istra 51,7 \%, ostatak Primorske Hrvatske 58,6 \%). No zato u Istri sva gospodarstva koja se promoviraju na internetu to čine na višejezičnoj web-stranici, dok je u ostatku Primorske Hrvatske taj udio nešto niži $(82,4 \%)$.

S putničkim agencijama surađuje 58,6 \% ispitanika. Suradnja je najslabije izražena u Zadarskoj subregiji, gdje s njima surađuju samo dva od sedam ispitanika. U Dubrovačko-neretvanskoj subregiji surađuje sedam od devet ispitanika, a u cijeloj Istarskoj subregiji suradnja je češća nego u ostatku Primorske Hrvatske za otprilike $7 \%$. S obzirom na to da su Istarska i Dubrovačko-neretvanska subregija najrazvijenije u pogledu agroturizma $\mathrm{i}$ istovremeno najsnažnije surađuju s putničkim agencijama, možemo ustvrditi kako je takva vrsta suradnje očito bitna za značajniju turističku valorizaciju ruralnog prostora. Suradnja s putničkim agencijama ovisi i o smještajnim kapacitetima. Od 24 TSOG-a koja su odgovorila da ne surađuju s agencijama devetnaest ih ima broj ležajeva manji od prosjeka svih gospodarstava Primorske Hrvatske (deset ležajeva). To je i logično jer nemaju kamo smjestiti potencijalno velik broj gostiju koji agencija može dovesti.

Većina ispitanika $(75,9 \%)$ tvrdi da lokalna i/ili županijska vlast potiče razvoj agroturizma, međutim od njih 44 čak $78 \%$ smatra kako to ne čini u dovoljnoj mjeri, a $11 \%$ da to čini u dovoljnoj mjeri opravdavajući to nemogućnostima većih poticaja u vrijeme ekonomske krize. Kada su ispitanici naveli da su iskusili određene poticaje od državnih ili upravnih tijela u praksi, slijedilo je pitanje kakvi su to točno poticaji bili. U većini slučajeva (52,5\%) bila je riječ o promoviranju TSOG-ova, a slijede porezne olakšice $(15,2 \%)$ i potpore za uređenje zemljišta (13,6 \%). Potpore za prekvalifikaciju $(5,1$
M. Košak,

K. Lugomer

The role of agrotourism in tourist season extension in

Littoral Croatia

Agroturizam u funkciji produljenja turističke sezone Primorske Hrvatske 
GEOGRAFSKI

GLASNIK

77/2, 141-168 (2015.) land purchase (13.6\%). Grants for retraining (5.1\%) and accommodation $(1.7 \%)$ occurred in a very poor measure. There had also been some non-refundable grants in various forms and the establishment of a special association for the promotion of agrotourism (Agrotourism Konavle) $^{14}$.

\section{Status and perspectives of agrotourism}

The last group of questions was used for the detection of the level of development of agrotourism and opportunities for future development. Special attention was paid to the real possibilities of agrotourism as a factor of the tourist season extension.

For this purpose, respondents gave ratings to the level of development of agrotourism in their county ( 1 = very poorly developed, 2 = poorly developed, 3 = medium developed, $4=$ well developed, 5 = very well developed). If we compare the average grade of the Istria sub-region and other sub-regions along the Littoral Croatia ${ }^{15}$, the ratio score is 2.79: 2.46 in favour of Istria. None of the 58 respondents rated the level of development of agrotourism in their county as very well developed (grade 5). This shows that even in the most developed tourist areas there is no total satisfaction with the level of development of agrotourism.

We also asked about deficiencies of agrotourism in the counties. Respondents mostly blame state or administrative bodies for the problems, which implies a lack of financial support and poor promotion (Tab. 2).

Interestingly enough, second place was taken by insufficient own engagement (too low private investment, weak own promotion, lack of concern on the part of young people, general lack of interest in capacity expansion, and lack of joint presentation of agrotourism by state or administrative bodies in terms of seeking better conditions, etc.). $93.1 \%$ of respondents think that agrotourism can contribute to tourist sea-
\%) i potpore za proširenje smještajnih kapaciteta $(1,7 \%)$ javljaju se u vrlo slaboj mjeri. Pod opcijom Ostalo našla su se uglavnom bespovratna sredstva u različitim oblicima te samo u jednom slučaju osnivanje posebne udruge za promicanje agroturizma (Agroturizam Konavle) $^{14}$.

\section{Stanje i perspektive agroturizma}

Posljednja tematska skupina anketnih pitanja poslužila je za detektiranje stanja razvijenosti agroturizma i mogućnosti za budući razvoj. Posebna je pozornost pritom posvećena razmišljanjima nositelja TSOG-ova o realnim mogućnostima agroturizma kao faktora produljenja turističke sezone.

U tu svrhu od ispitanika smo tražili da daju ocjenu stanja razvijenosti agroturizma u svojoj županiji (1 - vrlo slabo razvijen, 2 - slabo razvijen, 3 - srednje razvijen, 4 - dobro razvijen, 5 - prilično dobro razvijen). Usporedimo li prosječnu ocjenu Istarske subregije i ostalih subregija Primorske Hrvatske ${ }^{15}$ zajedno, odnos ocjena jest $2,79: 2,46$ u korist Istre. Od 58 ispitanika nitko nije stanje razvijenosti agroturizma u svojoj županiji ocijenio prilično dobro razvijenim (ocjena 5), što je pokazatelj da ni u najrazvijenijim turističkim regijama ne postoje osnove za potpuno zadovoljstvo stanjem razvijenosti agroturizma.

Ocjenu smo nadopunili mišljenjem ispitanika o nedostacima razvoja agroturizma u dotičnoj županiji. Za probleme ispitanici uglavnom krive državna ili upravna tijela, što podrazumijeva nedovoljnu financijsku potporu i slabu promociju tog tipa turizma (tab. 2).

$\mathrm{Na}$ drugome mjestu, zanimljivo je, nalazi se nedovoljan vlastiti angažman (premala vlastita ulaganja, slaba vlastita promocija, nezainteresiranost mladih i opća nezainteresiranost za proširenje kapacitetâ, nepostojanje zajedničkog nastupa agroturizama prema državnim ili upravnim tijelima u smislu traženja boljih uvjeta itd.).

14 Although this case is a kind of promotion of agrotourism by government or administrative authorities, it is specific because it has to deal with the creation of a special association. It is thus placed into the category Others and specially emphasized.

14 Iako je i ovdje riječ o svojevrsnoj promociji agroturizma od državnih ili upravnih tijela, slučaj je specifičan jer je posrijedi osnivanje posebne udruge koja to čini, pa je izdvojen u kategoriju Ostalo i posebno naglašen.

15 As in the case of the average number of beds, quantitative analysis would not make sense here because of the small number of respondents in the sub-regions.

15 Kao ni u slučaju prosječnog broja ležajeva kvantitativna analiza ovdje nema smisla zbog premalog broja ispitanika po subregijama. 
Tab. 2 Disadvantages of development of agrotourism according to the respondents, in their counties

Tab. 2. Nedostaci razvoja agroturizma u vlastitim županijama prema mišljenju Ispitanika

\begin{tabular}{|l|c|}
\hline \multicolumn{1}{|c|}{$\begin{array}{c}\text { Disadvantage / } \\
\text { Nedostatak razvoja }\end{array}$} & $\begin{array}{c}\text { Frequency (\%)/ } \\
\text { Učestalost } \\
\text { pojavljivanja (\%) }\end{array}$ \\
\hline $\begin{array}{l}\text { Insufficient engagement of state or administrative authorities (subsidies, promotion) / } \\
\text { Nedovoljan angažman vlasti (poticaji, promocija) }\end{array}$ & 24,7 \\
\hline Insufficient own engagement / Nedovoljan vlastiti angažman & 16,8 \\
\hline Legal constraints and difficulties / Pravna ograničenja i poteškoće & 14,9 \\
\hline Favouring maritime tourism / Favoriziranje maritimnog turizma & 12,9 \\
\hline $\begin{array}{l}\text { Insufficient own resources (finances, labour, accommodation) / } \\
\text { Nedostatak vlastitih resursa (financije, radna snaga, smještajni kapaciteti) }\end{array}$ & 9,9 \\
\hline Insufficient education / Nedovoljna educiranost & 6,9 \\
\hline $\begin{array}{l}\text { Other (uninformed tourists, lack of competitiveness, low population } \\
\text { density, underdevelopment of rural areas...) / Ostalo (neinformiranost turista, } \\
\text { nedostatak konkurencije, slaba naseljenost, zaostajanje ruralnog prostora...) }\end{array}$ & 13,9 \\
\hline \begin{tabular}{l} 
Total / Ukupno \\
\hline
\end{tabular} & 100,0 \\
\hline
\end{tabular}

son extension. Only one respondent thinks that this is not possible and 5.2\% do not know the answer. $88.9 \%$ of those who answered yes believe that agrotourism can play a bigger role in tourist season extension than "sun and sea" tourism. The remaining $11.1 \%$ do not know the answer (no one answered negatively). This confirms that scepticism and pessimism do not exist, but rather RTTF owners' firm belief in the importance of agrotourism in tourist season extension.

Respondents who answered affirmatively to the previous two questions were asked about measures needed to bring agrotourism into the role of tourist season extension. Among the answers, the group for improving and extending the offer prevailed, which is logical because of the low level of the quantity and diversity of agrotourism offer in most parts of the Littoral Croatia (with the exception of in Istria) (Tab. 3). Then there was the matter of increase in the engagement of state or administrative bodies and legislation improvement. This implies a reduction of the paperwork that hampers entrepreneurship and modification of low-quality and restrictive laws. As examples of illogical regulations, several respondents mentioned the ban on the employment of additional labour and identical payment for payroll taxes both for RTFFs and restaurants.
M. Košak,

K. Lugomer

The role of agrotourism in tourist season extension in

Littoral Croatia

Agroturizam u funkciji produljenja turističke sezone

Primorske Hrvatske
Da agroturizam može pridonijeti produljenju turističke sezone, smatra čak 93,1\% ispitanika. Samo jedan ispitanik tvrdi da to nije moguće, a 5,2\% ne zna odgovor. Od onih koji su potvrdno odgovorili 88,9 $\%$ smatra kako agroturizam može imati veću ulogu u produljenju turističke sezone od turizma „sunca i mora", a preostalih $11,1 \%$ ne zna odgovor (nitko nije odgovorio negativno). Potvrda je to odsutnosti skepticizma i pesimizma te čvrste uvjerenosti nositeljâ agroturizma u njegovu važnost u ublažavanju efekta sezonalnosti.

Ispitanici koji su potvrdno odgovorili na prethodna dva pitanja trebali su navesti što treba poduzeti kako bi agroturizam utjecao na produljenje turističke sezone. Među odgovorima prevladava skupina poboljšanja i proširenja ponude, što je i logično jer su kvantiteta i raznovrsnost agroturističke ponude u većem dijelu Primorske Hrvatske (osim Istre) na niskoj razini (tab. 3). Slijede povećanje angažmana državnih ili upravnih tijela i poboljsanje zakonodavstva. To podrazumijeva smanjenje papirologije, koja je inicijalni razlog za kočenje poduzetničkog duha te modifikaciju nedovoljno kvalitetnih i ograničavajućih zakona. Kao primjere nelogičnih propisa nekoliko je ispitanika istaknulo zabranu zapošljavanja dodatne radne snage i izjednačenost novčanih davanja agroturizma s restoranima. 
GEOGRAFSKI

GLASNIK

77/2,141-168 (2015.)

Tab. 3 Measures necessary for the significant impact of agrotourism on the tourist season extension

Tab. 3. Mjere potrebne za značajniji utjecaj agroturizma na produljenje turističke sezone

\begin{tabular}{|c|c|}
\hline $\begin{array}{l}\text { Measures / } \\
\text { Skupina mjera }\end{array}$ & $\begin{array}{l}\text { Frequency }(\%) / \\
\text { Učestalost } \\
\text { pojavljivanja }(\%)\end{array}$ \\
\hline $\begin{array}{l}\text { Improvement and diversification of attractions / } \\
\text { Poboljšanje i proširenje ponude }\end{array}$ & 31,4 \\
\hline $\begin{array}{l}\text { Increasing the involvement of authorities (subsidies, promotion, } \\
\text { organization of training and retraining) / Povećanje angažmana vlasti } \\
\text { (poticaji, promocija, organizacija edukacije i prekvalifikacije) }\end{array}$ & 18,0 \\
\hline $\begin{array}{l}\text { Improving legislation (laws, policies, procedures) / } \\
\text { Poboljšanje zakonodavstva (zakoni, strategije, procedure) }\end{array}$ & 16,8 \\
\hline $\begin{array}{l}\text { Increase and improve self-promotion / } \\
\text { Povećanje i poboljšanje samopromocije }\end{array}$ & 7,9 \\
\hline $\begin{array}{l}\text { Increasing co-operation with travel agencies / } \\
\text { Povećanje suradnje s putničkim agencijama }\end{array}$ & 7,9 \\
\hline $\begin{array}{l}\text { Other (improve the exchange of experiences, increase connectivity with } \\
\text { the cities on the coast, raising youth awareness...) / Ostalo (poboljšati razmjenu } \\
\text { iskustava, povećati povezanost s gradovima na obali, osvijestiti mlade...) }\end{array}$ & 18,0 \\
\hline Total / Ukupno & 100,0 \\
\hline
\end{tabular}

The last two questions in the survey included their own plans and plans of descendants related to the future development of agrotourism. It is encouraging that $96.6 \%$ of respondents plan to continue to engage in agrotourism and $58.6 \%$ have descendants who want to continue the agrotourism family business. $20.7 \%$ of descendants do not have such intentions, $12.1 \%$ are not sure, while the remainder are respondents without descendants.

\section{Discussion}

Based on the presented results of the survey we can conclude that agrotourism in Littoral Croatia is still in the initial phase of its development. Proof of this is the high proportion of RTFFs without accommodation or an insufficiently diversified and broad offer, as well as insufficient advertising. The main causes of such condition are insufficient engagement of state or administrative authorities and insufficient own engagement. Other causes are legal restrictions and favouring of "sun and sea" tourism. Thus, Hypothesis No. 4. on the causes of underdevelopment of agrotourism is not valid in its entirety because, along with the lack of interest on the part of government or administrative authorities, the key cause is poor self-effort.
Posljednja dva pitanja u anketi obuhvaćala su vlastite planove i planove potomaka vezane uz nastavak bavljenja agroturizmom. Ohrabruje podatak da se 96,6 \% ispitanika kani i dalje baviti agroturizmom te da 58,6 \% ispitanika ima potomke koji žele nastaviti obiteljski posao agroturizma. Kod 20,7 \% ispitanika potomci nemaju takvu namjeru, 12,1\% nije sigurno, a ostatak čine ispitanici bez potomaka.

\section{Rasprava}

$\mathrm{Na}$ osnovi iznesenih rezultata istraživanja možemo ustvrditi kako je agroturizam u Primorskoj Hrvatskoj i dalje u početnoj fazi razvoja. Dokaz za to jest visok udio TSOG-ova bez usluge smještaja, odnosno nedovoljno diverzificirana i široka ponuda te nedovoljno oglašavanje. Glavni su uzroci takva stanja nedostatan angažman državnih ili upravnih tijela i nedostatan vlastiti angažman. Slijede pravna ograničenja te favoriziranje turizma "sunca i mora”. Tako hipoteza br. 4 o uzrocima nedovoljne razvijenosti agroturizma ne vrijedi u cijelosti jer je uz nezainteresiranost državnih ili upravnih tijela ključni uzrok nedostatan vlastiti napor. 
As about $78 \%$ of the surveyed RTFFs are open all year round, it is evident that this is not the primary problem in setting up agrotourism in the function of mitigating the effects of seasonality. However, work should be done on increasing this percentage because the most common reason for closing doors to tourists at certain times of year is illogical, and that is the lack of tourists. This creates a vicious circle in which the seasonal work is the result of an insufficient number of tourists outside the summer season, and an insufficient number of tourists is the result of a lack of work and engagement. It is important to point out that 10 of the 13 RTFFs that do not operate the whole year are not co-operating with travel agencies, which is emerging as a potential stimulus of working and bringing tourists to their farms outside the summer season. Observing RTFFs that are open throughout the year, the tourist season for most of them starts in May and ends in September. That is an indication of their focus on the summer period. Agrotourism has the potential to become a more significant factor in tourist season extension, which confirms the almost unanimous view of RTTF owners on this issue, as well as on the issue of the claim that agrotourism in this sense has greater significance than "sun and sea" tourism. Thus, Hypothesis No.1., which highlights the current marginal role of agrotourism in tourist season extension, has been confirmed, yet it is not questioned its potential.

In connection with the previous thesis, it should be added that on the issue of reduction of the effects of seasonality in Littoral Croatia, the mitigating circumstance is that most of all the Croatian RTFFs are located there. This confirmed Hypothesis No. 2, while Hypothesis No. 3 has also been confirmed by calculating the coefficient of variation as an indicator of the strength of seasonality, whose spatial distribution indicates less expressed seasonality in some parts of the interior of Littoral Croatia. It is not correct to claim that the entire interior land area has better standing than the coastal areas and islands in terms of seasonality, because certain parts of the interior land, especially the Dalmatian hinterland, are problem areas affected by demographic extinction, while in some municipalities and cities, tourism activities do not exist at all.

The experience of many countries confirms the fact that the demands of tourists who select RTFFs as their destination have different requirements from those of tourists who choose the bathing resorts on the coast. However, this is not always the case (Lukić, 2000), as
Kako je oko $78 \%$ anketiranih TSOG-ova otvoreno cijele godine, evidentno je da to nije primarni problem $u$ postavljanju agroturizma $u$ funkciju ublažavanja efekta sezonalnosti. No valja poraditi i na povećanju tog postotka jer je najčešći razlog za zatvaranje vrata turistima u određeno doba godina nelogičan, a to je nedostatak turista. Time se stvara začarani krug u kojem je sezonski rad posljedica nedovoljnog broja turista izvan ljetne sezone, a nedovoljni broj turista rezultat nedostatnog rada i angažmana. Važno je istaknuti kako deset od trinaest TSOG-ova koji ne rade cijele godine, ne surađuje s putničkim agencijama, što se nameće kao mogući poticaj za rad i dovođenja turista izvan ljeta. Ako se gledaju gospodarstva koja nisu otvorena cijele godine, turistička sezona za većinu počinje u svibnju i završava u rujnu. To je pokazatelj njihove fokusiranosti na ljetno razdoblje. Agroturizam ima potencijal da postane značajniji faktor produljenja turističke sezone, što potvrđuje i gotovo jednoglasan stav nositelja TSOG-ova o tome, kao i o tvrdnji da agroturizam u tom smislu ima veće značenje od turističkog proizvoda „sunca i mora”. Tako je potvrđena hipoteza br. $1 \mathrm{~s}$ početka rada kojom se ističe trenutačno marginalna uloga agroturizma $u$ produljenju sezone, ali se pritom ne dovodi u pitanje njegov potencijal $\mathrm{u}$ tome.

U vezi s prethodnom tezom valja dodati kako je u problematici ublažavanja efekta sezonalnosti u Primorskoj Hrvatskoj olakotna okolnost što je tamo locirana većina TSOG-ova cijele Hrvatske. Time je potvrđena hipoteza br. 2, a hipoteza br. 3 također je potvrđena izračunavanjem koeficijenta varijacije kao pokazatelja jačine sezonalnosti, čija prostorna distribucija upućuje na slabije izraženu sezonalnost $\mathrm{u}$ pojedinim dijelovima unutrašnjosti Primorske Hrvatske. Nije ispravno tvrditi da cijela unutrašnjost u smislu sezonalnosti bolje stoji od priobalja i otoka jer su određeni dijelovi unutrašnjosti, osobito Dalmatinske zagore, problemska područja zahvaćena demografskim izumiranjem, pa u nekim općinama i gradovima turističkih kretanja uopće nema.

Iskustvo brojnih zemalja potvrđuje činjenicu kako su zahtjevi turista koji kao odredište odabiru TSOG-ove drugačiji od zahtjeva turista koji biraju kupališna središta na obali. No to nije uvijek tako
M. Košak, K. Lugomer

The role of agrotourism in tourist season extension in

Littoral Croatia

Agroturizam u funkciji produljenja turističke sezone Primorske Hrvatske 
HRVATSKI

GEOGRAFSKI

GLASNIK

77/2,141-168 (2015.) confirmed by the results of this research. According to estimates by the RTFF owners, their guests most often (43\%) come in casually while their final destinations are coastal tourist centres. Although this is not a marked predominance of casual tourists, and regional differences are also present, it can be said that Hypothesis No. 5 on independence of agrotourism from tourist arrivals in coastal areas has not been confirmed.

It has already been said that more than half of respondents have descendants who are planning to continue the family business of agrotourism. One should add the $12 \%$ respondents whose descendants are still not sure, so there is a possibility that some of them would eventually continue the family business. Despite the poor demographic picture of a larger part of the rural areas on the Croatian coast, these data suggest that most of the existing rural households will have a work force for the near future, thus disproving Hypothesis No. 6. However, it should be pointed out that the negative demographic processes will have long-term impact on population viability of any development in the interior of the Littoral Croatia and on the islands, including the development of agrotourism. As for the development of agrotourism in Croatia, in addition to maintaining the existing resources, the formation of new RTFFs is most important, and there is a need to intensify efforts in implementing stimulating measures and immigration population policy. Otherwise, the emergence of new RTFFs will weaken, and some of the existing farms, due to lack of interest of some future generations, will disappear.

In the case of most or all the sub-regions of the Littoral Croatia, some of the shortcomings, needs and possibilities are repeating themselves, so there is the need for the intervention of the general government or administrative bodies at the national level. First of all, it is necessary to develop a National Strategy for the development of rural tourism and implement it in the existing Rural Development Strategy of the Republic of Croatia, in accordance with the strategic guidelines of the General Plan and the Tourism Development Strategy of the Republic of Croatia by the year 2020. The Strategy must encompass the totality of assumptions of the physical and human geography and possibilities of strengthening agrotourism in all periods of the year. In addition, it must be based on the determination of priority areas and steps of development of agrotourism for all of Croatia, as well as on regional level.
(Lukić, 2000), što potvrđuju i rezultati ovog istraživanja. Prema procjeni nositelja TSOG-ova, njihovi gosti najčešće (43\% ispitanika) dolaze usputno, dok su im konačna odredišta obalna turistička središta. Iako nije riječ o izrazitoj prevlasti usputnih turista, a prisutne su i regionalne razlike, ipak se može ustvrditi kako hipoteza br. 5 o neovisnosti agroturizma o dolascima turista $\mathrm{u}$ obalni prostor nije potvrđena.

Rečeno je da više od polovine ispitanika ima potomke koji planiraju nastaviti obiteljski posao agroturizma. Tome valja pridodati $12 \%$ ispitanika čiji potomci još nisu odlučili, pa postoji vjerojatnost da će i neki od njih naposljetku nastaviti obiteljski posao. Unatoč depresivnoj demografskoj slici većeg dijela ruralnog prostora Primorske Hrvatske ti podaci sugeriraju da će većina postojećih seljačkih gospodarstava imati radnu snagu za bližu budućnost, čime je opovrgnuta hipoteza br. 6. Ipak, valja upozoriti kako će se negativni demografski procesi dugoročno odraziti na populacijsku održivost bilo kakva razvoja u unutrašnjosti Primorske Hrvatske i na otocima, pa tako i razvoja agroturizma. Kako je za razvoj agroturizma u Hrvatskoj, osim održavanja postojećih, od prvorazredne važnosti nastajanje novih TSOG-ova, treba intenzivirati napore u provedbi pronatalitetne i imigracijske populacijske politike. U protivnome će nastajanje novih gospodarstava oslabjeti, a neka će od postojećih zbog nezainteresiranosti dijela budućih naraštaja propasti.

U slučajevima većine ili svih subregija Primorske Hrvatske neki se nedostaci, potrebe i mogućnosti razvoja ponavljaju, pa otvaraju potrebu za općom intervencijom državnih ili upravnih tijela na nacionalnoj razini. Prije svega, treba izraditi Nacionalnu strategiju razvoja ruralnog turizma i implementirati je u postojeću Strategiju ruralnog razvoja Republike Hrvatske u skladu sa strateškim smjernicama Glavnog plana i Strategije razvoja turizma Republike Hrvatske do 2020. godine. Strategija mora obuhvaćati ukupnost fizičkogeografskih i društvenogeografskih pretpostavki i mogućnosti jačanja agroturizma u svim godišnjim razdobljima. Također, mora se temeljiti na određivanju prioritetnih područja i koraka razvoja agroturizma na razini cijele Hrvatske i na regionalnoj razini. 
After creation of the Strategy, which itself must contain all of the following measures and steps, the improvement of the quality of legislation should follow. The very slow road towards the establishment of appropriate conditions for initiating RTFFs acts in a demotivating way and hampers entrepreneurship. After resolving the formal legal issues, providing information and education for farmers about the mutual benefits that agrotourism can bring to them should follow, but these would also be a benefit to the entire economy of the country. Apart from the usual mass media such as the Internet and brochures, seminars and courses should be organized, with the involvement of tourist boards. Fairs should be organized where businessmen can exchange experience, further educate themselves and undertake promotion. One of the measures must be the provision of grant funds for visiting fairs by the local community, because many of the fairs usually take place in the major cities, which is a problem.

After creating the basic conditions for the development of agrotourism (i.e. the basic phase), further strengthening and creating of conditions for the formation of an all-year tourism product would be on the agenda in the second, so-called phase of competition and rivalry. In order to increase tourist traffic by operations of agencies, in a first step of this phase there should be an increase in accommodation capacities. The reason is obvious, confirmed by the research - $80 \%$ of the total number of RTFFs that do not collaborate with the agencies have less than the average number of beds (10). Increase of capacities would be achieved with incentives given by state or administrative bodies, while a small part of the stimulus, and the remaining residual incentives would be left at the disposal to RTFF owners, although these would still have to be invested in the development of agrotourism.

After creating the financial prerequisites for increasing capacities, acceleration of development will be achieved by creating an entrepreneurial and competitive environment by organizing competition. According to predefined criteria, there would be an award for the RTFFs which, using their own funds and funds obtained under Step 4, would bring their economies up to the highest levels. Awarded RTFFs would serve as an example and encourage others to invest maximum effort in equipping farms and diversification of supply. Since one moment in the summer for the acceptance of tour-
Nakon izrade strategije, koja treba sadržavati sve sljedeće mjere i korake, valja poboljšati kvalitetu zakonske regulative. Vrlo spor put prema stjecanju odgovarajućih uvjeta za začetak pojedinih agroturizama djeluje demotivirajuće i koči poduzetništvo. Nakon rješavanja formalno-pravnih problema slijede informiranje i edukacija poljoprivrednika o uzajamnoj koristi koju agroturizam donosi njima, ali i cjelokupnom gospodarstvu zemlje. Osim uobičajenih sredstava informiranja poput interneta i brošura treba organizirati seminare i tečajeve, uz angažman turističkih zajednica, te sajmove na kojima gospodarstvenici mogu razmjenjivati iskustva, dodatno se educirati i promovirati. Jedna od mjera moraju biti i bespovratna sredstava koja lokalna zajednica daje za odlazak na sajmove jer se veliki sajmovi obično održavaju u većim gradovima, što predstavlja problem.

Nakon stvaranja osnovnih uvjeta za razvoj agroturizma (tzv. temeljna faza) daljnje jačanje i stvaranje pretpostavki za formiranje cjelogodišnjega turističkog proizvoda dolazi na red u drugoj, tzv. fazi konkurencije i nadmetanja.

Kako bi se povećanje turističkog prometa operacijama agencije moglo provesti, u prvom koraku navedene faze treba povećati smještajne kapacitete. Razlog je očit, potvrđen i istraživanjem - od ukupnog broja TSOG-ova koji ne surađuju s agencijama, njih $80 \%$ ima manje od prosječnog broja ležajeva (deset). Povećanje kapaciteta ostvarili bi se poticajima državnih ili upravnih tijela, pri čemu bi manji dio poticaja, odnosno preostali, rezidualni poticaji, bili ostavljeni na fleksibilnije raspolaganje nositeljima TSOG-ova, no svejedno bi morali biti uloženi u razvoj agroturizma.

Nakon stvaranja financijskih preduvjeta za povećanje kapaciteta, ubrzanje razvoja ostvarit će se stvaranjem poduzetničke i natjecateljske klime organizacijom natječajâ. Prema unaprijed definiranim kriterijima nagrađivat će se TSOG-ovi koji, upotrebljavajući vlastita sredstva i sredstva dobivena u koraku br. 4., dovedu svoje gospodarstvo do najviše razine. Nagrađena gospodarstva poslužit će kao primjer i potaknuti druge na maksimalno ulaganje truda u opremanje gospodarstava i proširenje ponude. Kako u jednom trenutku prihvat turista ljeti, makar i maksimalan, neće biti dovoljan za
M. Košak, K. Lugomer

The role of agrotourism in tourist season extension in

Littoral Croatia

Agroturizam u funkciji produljenja turističke sezone

Primorske Hrvatske 
GEOGRAFSKI

GLASNIK

77/2,141-168 (2015.) ists, even at the maximum point, will not be enough for competition, the expansion of services to other months will become a necessity, which implies the goal of all the above measures: reduction of seasonality.

One of the concrete measures for mitigating the effects of seasonality is to create conditions and to encourage RTFFs to organize events in the non-summer months. In this way, RTFFs, which have good ideas and implement innovations, would have the possibility of implementing these measures. Thereby, the so-called "bottom-up approach" would be achieved, which is important for profiling RTFFs as destinations that offer a rich tourist product, wider than the "sun and sea" tourism, which is limited to the summer period. This measure is based on the positions of almost all respondents who believe that agrotourism, with appropriate development policy, can extend the tourist season.

These components of the general model are shown in Table 4.

Successive steps for the development of agrotourism should be complemented by more general measures with the aim of revitalization of rural areas. These measures are related to the demographic and economic revitalization and regional integration of rural areas.

Following the model from Pejnović (2006), which emphasizes the importance of a coherent functional organization of space with the purpose of sustainable development of rural areas, more attention in the form of studies and funds should be invested in giving central functions to sub-regional centres in the heartland and on the islands in Littoral Croatia. This measure must be followed by stimulating population policy, because this is key for the existence of tourism and for work during the whole year. This need is confirmed by some municipalities in the Zadar and Šibenik-Knin County, where there have been no recorded overnight stays in the past five years.

To prevent permanent emigration of labour, a wide range of services in the nearest settlements with a higher level of centrality should be provided. Examples of such settlements are Pazin, Knin, Sinj, Imotski, Ploče and Metković as stronger sub-regional centres and Buje, Buzet, Benkovac, Obrovac, Drniš, Vrgorac and Opuzen as weaker sub-regional centers (Lukić, 2012). međusobno konkuriranje, proširenje usluga prema ostalim mjesecima postat će potreba, što za sobom povlači cilj svih navedenih mjera: ublažavanje efekta sezonalnosti.

Jedna od konkretnih mjera za ublažavanje efekta sezonalnosti jest i stvaranje uvjeta i poticanje TSOG-ova na organiziranje manifestacija u neljetnim mjesecima. Na taj bi način gospodarstva koja imaju kvalitetne ideje i inovacije imala mogućnost implementacije tih mjera. Time se ostvaruje tzv. „pristup odozdo prema gore”, što je važno za profiliranje gospodarstava kao odredišta koja nude bogat turistički proizvod, širi od turističkog proizvoda „sunca i mora”, koji je ograničen na ljeto. Ta mjera temelji se na stavovima gotovo svih ispitanika, koji smatraju da agroturizam pravilnom politikom $\mathrm{ra}^{-}$ zvoja može produljiti turističku sezonu.

Navedene sastavnice općeg modela navode se $u$ tablici 4.

Sukcesivni koraci usmjereni na razvoj agroturističke djelatnosti moraju biti praćeni općenitijim mjerama čiji će cilj biti i revitalizacija ruralnog prostora. Mjere se tiču demografske i gospodarske revitalizacije te regionalne integracije ruralnog prostora.

$\mathrm{Na}$ tragu modela D. Pejnovića (2006), koji u svrhu održivog razvoja ruralnih područja ističe važnost koherentne funkcionalne organizacije prostora, prijedlog je da se više pozornosti u obliku studija i financija uloži u opremanje subregionalnih centara unutrašnjosti i otoka Primorske Hrvatske centralnim funkcijama. Tu mjeru moraju pratiti poticajne mjere populacijske politike jer je postojanje povoljnih dinamičkih i strukturnih obilježja stanovništva ključna pretpostavka postojanja turističke djelatnosti uopće, a pogotovo rada cijele godine. Potvrđuju to i neke općine u Zadarskoj i Šibensko-kninskoj županiji gdje u proteklih pet godina nema zabilježenih turističkih noćenja.

Za sprečavanje trajne emigracije radne snage valja osigurati širok raspon usluga u najbližim naseljima višeg stupnja centraliteta. Primjeri su takvih naselja Pazin, Knin, Sinj, Imotski, Ploče i Metković kao jači subregionalni centri te Buje, Buzet, Benkovac, Obrovac, Drniš, Vrgorac i Opuzen kao slabiji subregionalni centri (Lukić, 2012). 


\section{no. / Description / Opis koraka \\ Goal / Cilj koraka}

\section{Fundamental phase / Temeljna faza}

Develop a comprehensive strategy for the development of rural tourism as a factor of inte-

1. gral development. / Izraditi cjelovitu strategiju razvoja ruralnog turizma kao čimbenika integralnog razvoja

Solve problems of slow administration and poor-quality legal framework. Consult with owners who can give the most useful input.

2. Riješiti probleme spore administracije i nedovoljno kvalitetnih zakonskih regulativa savjetujući se sa samim nositelijima TSOG-ova, koj najbolje mogu upozoriti na ključne propuste

Increase the quality of information on agrotourism and organize education for RTFFs.

3. Povećati kvalitetu sustava informiranja o agroturizmu i organizirati edukaciju članova seljačkih gospodarstava

- create concrete short-term and long-term plans for development and tourist season extension

- stop the marginalization of rural areas

- sustainable development and improved quality of life in rural areas

- systematic development of rural tourism as a recognizable brand in Croatia

- kreiranje konkretnih kratkoročnih i dugoročnih planova razvoja i produljenja turističke sezone

- prestanak marginalizacije ruralnog prostora

- racionalno korištenje resursima, održivi razvoj i poboljšanje kvalitete života u ruralnom prostoru

- sustavno razvijanje ruralnog turizma kao novoga prepoznatljivog brenda Hrvatske

- provide formal and legal framework for the development of agrotourism which leads to an increase of those interested in this type of tourism and to strengthen the entrepreneurship - simplify the procedure of opening new RTFFs which leads to a more dynamic development of agrotourism

- osiguravanje formalno-pravnih okvira razvoja agroturizma, što dovodi i do povećanja broja zainteresiranih za taj tip turizma i jačanja poduzetničkog duha

- ubrzavanje procedure otvaranja novih TSOG-ova, što dovodi do dinamičnijeg razvoja agroturizma

- education of rural area inhabitants about agrotourism as an option for increase income, leading to a strengthening of activity and preventing depopulation

- education for RTFFs on the essential regulations and elements of the tourist attractiveness and on necessary measures of planning and control, with the aim of creating awareness about the importance of diversification of supply for the development of agrotourism and about the potential hazards that can have harmful social, economic and environmental consequences

- educiranje stanovnika ruralnog prostora o agroturizmu kao opciji povećanja dohotka, što dovodi do jačanja djelatnosti i prevencije depopulacije rurisa

- upoznavanje subjekata koji se bave agroturizmom s osnovnim propisima i elementima turističke atrakcijske osnove te s potrebnim mjerama planiranja i kontrole, s ciljem stvaranja svijesti o važnosti diverzifikacije ponude za razvoj agroturizma, te s potencijalnim opasnostima koje mogu uzrokovati štetne društvene, ekonomske i ekološke posljedice

\section{Competition phase / Faza nadmetanja}

Assign initial incentives (grants and cheap loans), mostly for the construction or expansion of existing accommodation facilities but also for improving various elements of agrotourism (self-promotion, landscaping, etc.)./

4. Dodijeliti inicijalne poticaje (bespovratn sredstva i povoljne kredite), od kojih ce već dio biti namijenjen za gradnju ili proširenje postojećih smještajnih kapaciteta, a ostatak za unapređenje različitih elemenata agroturizma (samopromocija, uređenje zemljišta i sl.)

- establishment and / or intensifying co-operation with travel agencies, which will lead to larger tourist traffic

- longer stays which generate greater consumption on RTFFs, thus increasing income, quality and experience of staying and stimulating further arrivals

- flexible and heterogeneous allocation of the remaining assets, allowing to owners to design and implement their own ideas, associated with step $5 \mathrm{a}$

- utemeljenje i/ili intenziviranje suradnje s putničkim agencijama, što će dovesti do većeg obujma turističkog prometa

- duži boravak gostiju, što za sobom povlači i veću konzumaciju hrane na samom gospodarstvu, a to ne samo da povećava prihod gospodarstva već i podiže kvalitetu ponude i doživljaj boravka te potiče dalinju potražnju i upućivanje preporuka novim potencijalnim turistima

- fleksibilnija i heterogenija namjena preostalih sredstava, koja nositeljima TSOG-ova omogućuje da osmisle i provedu vlastite ideje vezane uz agroturizam, a povezana je s korakom 5. a

- strengthening of agrotourism that becomes more attractive to potential tourists outside the summer and becomes a strong reason for visiting

- encouraging creativity and innovation

Encourage the creation of new cultural events - encouraging a bottom-up approach which emphasizes the importance of the participation of (with the emphasis on non-summer period), and support best ideas with tax breaks $5 . a^{*}$ and cheap defined purpose loans. / Potaknut osmišljavanje novih kulturnih manifestacija ( naglaskom na neljetno razdoblje) te najbolje ideje poduprijeti poreznim olakšicama i povoljnim namjenskim kreditima

- encouraging co-operation among local agrotourisms to strengthen the recognition of local identity

- jačanje turističkog destinacijskog proizvoda, koji postaje privlačniji potencijalnim turistima izvan ljeta i postaje dovoljno jak razlog da uopće dođu

- poticanje kreativnosti i inovacija

- poticanje pristupa odozdo prema gore, kojim se ističe važnost sudjelovanja lokalne zajednice u donošenju odluka značajnih za pokretače agroturizma

- poticanje suradnje među lokalnim TSOG-ovima s ciljem jačanja prepoznatliivosti lokalnog identiteta

- encouraging quality management with residual financial resources

Announce tenders with defined conditions that agrotourisms must achieve in a specified period to be eligible for additional incentives, and finally, after the deadline, award prizes. /

5.b* Raspisati natječaje s definiranim uvjetima koje TSOG-ovi moraju ispuniti u određenom razdoblju kako bi ostvarili pravo na dodatne poticaje te na kraju, nakon isteka roka, dodijeliti nagrade

- creating competitiveness, strengthening quality and dynamic development

- enrichment and improvement of the existing tourism offer, compensation in case of insufficient food production and easier adjustment of the original farmers to tourism activities - providing examples and encouraging other farmers to engage in agrotourism

- poticanje što kvalitetnijeo raspolaganja rezidualnim financijskim resursima

- stvaranje natjecateljske klime, poboljšavanje kvalitete i dinamičniji razvoj

- obogaćivanje i unapređenje postojeće turističke ponude, kompenzacija u slučaju nedostatne proizvodnje hrane te lakša prilagodba izvornih poljoprivrednika na bavljenje turizmom

- pružanje primjera drugim poljoprivrednicima i poticanje drugih poljoprivrednika na bavljenje agroturizmom

The role of agrotourism in tourist season extension in

Littoral Croatia

Agroturizam u

funkciji produljenja turističke sezone

Primorske Hrvatske

\footnotetext{
* parallel implementation of steps $5 \mathrm{a}$ and $5 \mathrm{~b}$

* Provedba koraka 5. a i 5. b odvija se paralelno.
} 
GEOGRAFSKI

GLASNIK

77/2,141-168 (2015.)

\section{Conclusion}

Based on presented results of the research and a general model, here are some conclusions:

1. Issues of the tourist season duration are very complex and must be viewed in relation to the complete spectrum of physical and social geographic elements and factors. They are strongly linked with the issue of the revitalization of rural areas through multi-sector economic development as an element of integrated rural development.

2. Most of the Croatian RTFFs are in Littoral Croatia, with emphasis on the Istria and $\mathrm{Du}-$ brovnik-Neretva Counties.

3. Seasonality of tourism in Littoral Croatia is less pronounced in the heartland than along the coast, which is an initial pledge for agrotourism becoming a factor in tourist season extension.

4. Most of the RTFFs are open during all the year, so this is not the major problem of seasonality. The larger problem lies in the fact that most of the RTFFs record the maximum stays in the summer, which means that promotion is still not focused enough to convince tourists to come more in other periods of the year.

5. Considering the example of Istria, the formula of successful agrotourism must contain a wide range of content with an emphasis on participation in agricultural activities. Another important ingredient is support from state or administrative bodies, which is stronger in Istria than in the rest of Littoral Croatia, but it can and must be increased. It is also important that RTFFs do not necessarily need to be final destinations in order to be successful, but in this case very high standard of marketing activities is required.

6. It is clear that there is motivation, initial optimism, hope to remedy the situation, a wish for greater competition and the prevailing desire of descendants to continue the family business. This must be exploited. Otherwise, disappointment and abandonment of agrotourism will follow, which will, due to lack of income from agriculture, lead to further depopulation and economic decline of rural areas in Littoral Croatia.

\section{Zaključak}

$\mathrm{Na}$ osnovi iznesenih rezultata istraživanja te općeg modela razvoja moguće je postaviti sljedeće zaključne točke:

1. Problematika trajanja turističke sezone kompleksna je, mora se promatrati u ovisnosti o cjelovitom spektru fizičkogeografskih i društvenogeografskih elemenata $\mathrm{i}$ faktora te je neraskidivo povezana $\mathrm{s}$ problematikom revitalizacije ruralnog prostora preko multisektorskoga gospodarskog razvoja kao elementa integralnoga ruralnog razvoja.

2. U Primorskoj Hrvatskoj nalazi se većina TSOGova Hrvatske, s naglaskom na Istarsku i Dubrovačko-neretvansku županiju.

3. Sezonalnost turizma u Primorskoj Hrvatskoj slabije je izražena u unutrašnjosti Primorske Hrvatske nego u priobalju, što je inicijalni zalog da agroturizam postane faktor produljenja turističke sezone.

4. Otvorenost gospodarstava turistima tijekom cijele godine nije glavni problem sezonalnosti jer je većina otvorena cijele godine. Veći je problem činjenica da većina TSOG-ova i dalje bilježi maksimum noćenja ljeti, što znači da promocija još nije $\mathrm{u}$ dovoljnoj mjeri zainteresirala turiste za dolazak izvan ljeta.

5. Razmatrajući istarski primjer, formula uspješnog agroturizma mora sadržavati širok raspon sadržaja s naglaskom na sudjelovanje u poljoprivrednim aktivnostima. Važna je i potpora državnih ili upravnih tijela, koja je u slučaju Istre jača nego u ostatku Primorske Hrvatske mada i ondje može i mora biti veća. Također je značajno da TSOG-ovi ne moraju nužno biti krajnja odredišta kako bi bili uspješni, no u tom je slučaju potreban jako kvalitetan marketing.

6. Evidentno je kako motiviranost, početni optimizam, nada u popravljanje stanja, želja za postojanjem veće konkurencije te prevladavajuća želja potomaka za nastavkom obiteljskog posla agroturizma postoje i to treba iskoristiti. U protivnome će slijediti razočaranje i odustajanje od djelatnosti, što će, zbog nedostatnog prihoda od same poljoprivrede, dovesti do daljnjega demografskog pražnjenja i gospodarskog propadanja ruralnog prostora Primorske Hrvatske. 
7. Existing accommodation is currently too small for significant income from agrotourism and accommodation extension must be among the first steps in future development strategies. This is justified by the fact that better co-operation with travel agencies, which could lead to an increasing number of tourists, is not possible without sufficient accommodation facilities. However, the risk of exceeding the tourism carrying capacity must also be taken into account. This could occur in the case of uncontrolled expansion, and it could disturb the primary ambience that originally attracted tourists and brings into question the long-term sustainability of agrotourism.

Our thanks are due to the surveyed RTFF owners in Littoral Croatia, as well as to Departments of Tourism of the Chambers of Economy of the individual counties in Littoral Croatia, which gave us data about registered RTFFs. In addition, we are grateful to the Secretary of the Community of Rural Tourism in the Croatian Chamber of Economy, to the Secretary of the Ministry of Tourism and to Nikola Cinkopan from the county Chamber of Economy in Pula, for our discussions about the situation in agrotourism in Croatia.
7. Prosječni postojeći smještajni kapaciteti trenutačno su premali za značajnije uprihođivanje od agroturizma i njihovo proširenje mora biti među prvim koracima budućih strategija razvoja. Takav stav opravdan je činjenicom da svrhovitija suradnja s putničkim agencijama, koja bi mogla voditi povećanju broja turista, nije moguća bez dovoljnih smještajnih kapaciteta. No valja upozoriti na opasnost od prekoračenja turistički nosivoga kapaciteta, koje može nastupiti u slučaju stihijskog širenja smještajnih jedinica, narušiti izvornu ambijentalnost koja je izvorno privlačila turiste i dovesti dugoročnu održivost agroturizma u pitanje.

Zahvaljujemo anketiranim nositeljima TSOGova u Primorskoj Hrvatskoj na iskazanoj susretljivosti te odjelima za turizam županijskih gospodarskih komora županija Primorske Hrvatske koji su nam ustupili podatke o registriranim TSOG-ovima. Zahvaljujemo i tajnici Zajednice ruralnog turizma Hrvatske gospodarske komore, tajnici Ministarstva turizma te Nikoli Cinkopanu iz $\check{Z}{ }^{-}$ panijske komore Pula na izdvojenom vremenu za istraživački razgovor.
Baćac, R., 2011: Priručnik za bavljenje seoskim turizmom, Ministarstvo turizma Republike Hrvatske, Zagreb.

Blažević, I., 2003: Turistička geografija Hrvatske, Školska knjiga, Zagreb.

Breiling, M., 2005: Rural Tourism: Experience from Austria and Opportunities for Japan, prezentacija u okviru Kinki Meeting, 6. kolovoza 2005., Hokudancho, Hyogo,

http://www.breiling.org/awaji/lect/RuralTourisminAustria.pdf (29.02.2013.)

Brščić, K., Franić, R., Ružić, D., 2010: Why Agrotourism - owner's opinion, Journal of Central European Agriculture 11 (1), 31-42.

Curić, Z., Glamuzina, N., Opačić, V. T., 2012: Contemporary Issues in the Regional Development of Tourism in Croatia, Hrvatski geografski glasnik 74 (1), $19-40$.
Defilippis, J., 1993: Promjene zemljišnih kapaciteta i posjedovne strukture obiteljskih gospodastava Hrvatske, Sociologija sela $31(3 / 4), 165-171$

Demonja, D., Ružić, P., 2010: Ruralni turizam u Hrvatskoj (s hrvatskim primjerima dobre prakse i europskim iskustvima), $\mathrm{Me}$ ridijani, Zagreb.

Jelinčić, D. A., Agroturizam u europskom kontekstu, Studia Ethnologica Croatica 19 (1), 269-291.

Kušen, E., 1995: Turizam na seljačkim gospodarstvima, Turizam 43 (7-8), 127133.

Lukić, A., 2000: Ruralni turizam - čimbenik integralnog razvitka ruralnog prostora Hrvatske: od mašte do stvarnosti, Geografski horizont 46 (1/2), 7-31.

Lukić, A., 2012: Mozaik izvan grada - tipologija ruralnih $i$ urbaniziranih naselja Hrvatske, Meridijani, Samobor.
Papić, M., 2010: Primijenjena statistika u MS Excelu, Zoro, Zagreb-Sarajevo.

Pejnović, D., 2006: Održivi razvoj naseljenosti na krškom području $\mathrm{Hr}-$ vatske, Hrvatski krš i gospodarski razvoj (Gospić-Zagreb, 2005), Zagreb, 19-31.

Roberts, L., Hall D. 2001: Rural Tourism and Recreation: Principles to Practice, CABI Publishing, London.

Towards Quality Rural Tourism: Integrated quality management (IQM) of rural destinations, Luxembourg: European Commission, 2000. http://ec.europa.eu/ enterprise/sectors/tourism/files/studies/ towards_quality_tourism_rural_urban_ coastal/iqm_rural_en.pdf (28.02.2013.)
M. Košak,

K. Lugomer

The role of agrotourism in tourist season extension in

Littoral Croatia

Agroturizam u funkciji produljenja turističke sezone Primorske Hrvatske

Acknowledgement Zahvala

Literature Literatura 
HRVATSKI

GEOGRAFSKI

GLASNIK

77/2,141-168 (2015.)
Sources

Izvori

Glavni plan i Strategija razvoja turizma Republike Hrvatske za razdoblje do 2020. godine, Ministarstvo turizma, http://www.mint.hr/ UserDocsImages/121019-strategija1.pdf (27.02.2013.)

Press and statistical reports, Tourism in 2008, 2009, 2010, 2011, 2012, http://www.dzs.hr/ (19.03.2013)

Priopćenja i statistička izvješća, Turizam u 2008., 2009., 2010., 2011., 2012., http://www.dzs.hr/ (19.03.2013)

Statistical Yearbook of the Republic of Croatia 2012, Croatian Bureau of Statistics, Zagreb, 2013.

Statistički ljetopis Republike Hrvatske 2012., Državni zavod za statistiku, Zagreb, 2013.

\section{Authors}

Marko Košak mark@@zelena-akcija.hr

Autori

mag. educ. geogr., Friends of the Earth Croatia, Frankopanska 1, Zagreb

Karlo Lugomer

MSc, Jasenovačka 3, 10040 Zagreb

168 